University of Louisville

ThinkIR: The University of Louisville's Institutional Repository

Electronic Theses and Dissertations

8-1962

\title{
A history of Kentucky Home School for Girls from 1863 to 1913.
}

Florence Whiteley Dickerson

University of Louisville

Follow this and additional works at: https://ir.library.louisville.edu/etd

Part of the Education Commons

\section{Recommended Citation}

Dickerson, Florence Whiteley, "A history of Kentucky Home School for Girls from 1863 to 1913." (1962). Electronic Theses and Dissertations. Paper 2883.

https://doi.org/10.18297/etd/2883

This Master's Thesis is brought to you for free and open access by ThinkIR: The University of Louisville's Institutional Repository. It has been accepted for inclusion in Electronic Theses and Dissertations by an authorized administrator of ThinkIR: The University of Louisville's Institutional Repository. This title appears here courtesy of the author, who has retained all other copyrights. For more information, please contact thinkir@louisville.edu. 
A HISTORY OF KENTUCKY HOME SCHOOL FOR GIRLS

FROM 1863 TO 1913 
A HISTORY OF KENTUCKY HONE SCHOOL FOR GIRLS FR OM 1863 TO 1913

\author{
A Thesis \\ Presented to
}

the Faculty of the Graduate School

University of Louisvilie

In Partial Fulfillnent

of the Requirements for the Degree

Master of Arts

Department of Education

by

Florence Whiteley Dickerson

August 1962 
Approved by a Reading Comnittee composed of the following members;
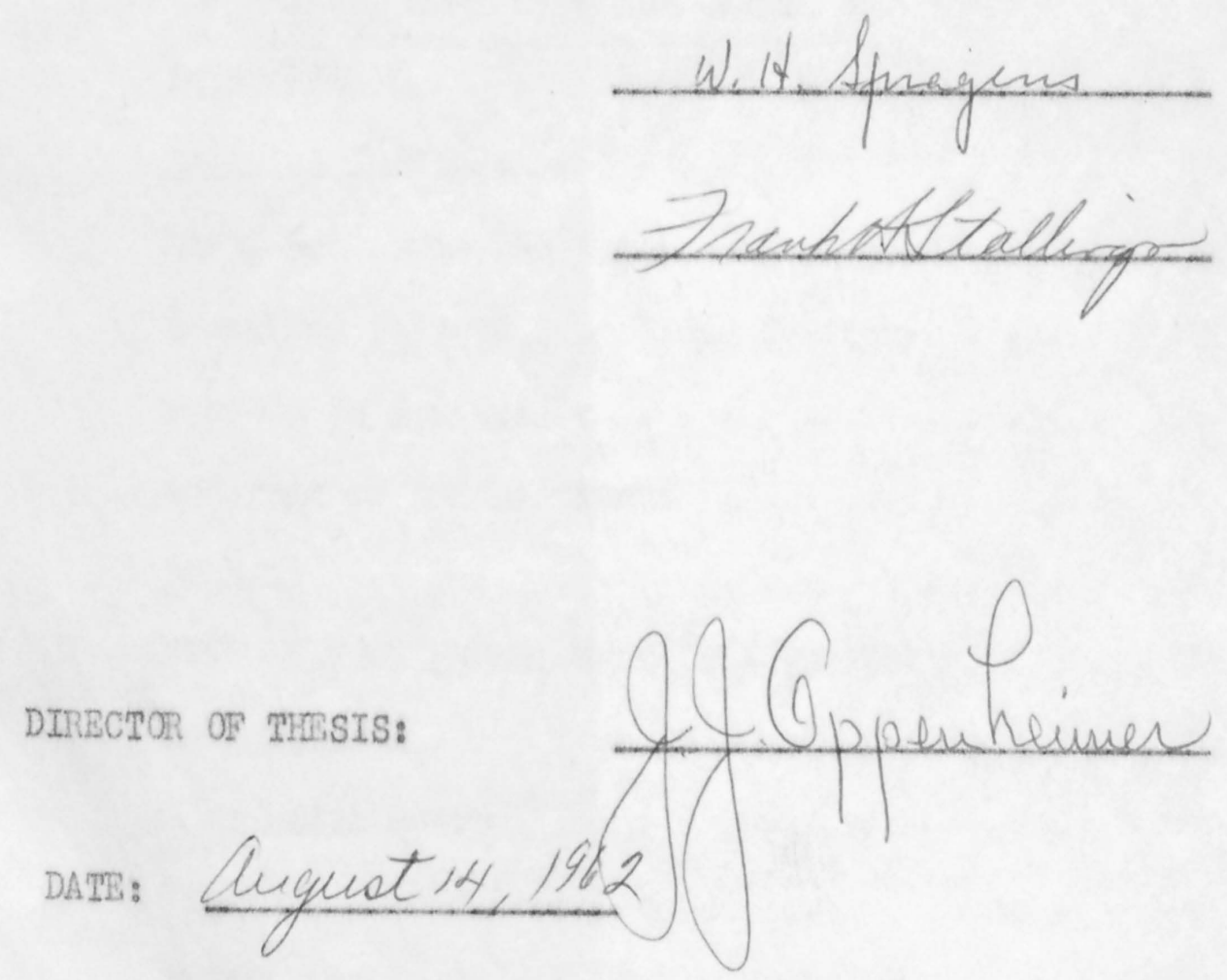
ACKNOWLEDGEMENTS

I an grateful for the time and information given we by former students of Kentucky Home School, Miss Henrietta Gray, Miss Amelia Moody, and Mrs. James Dorsey. I an most appreciative of Dr. Oppenheimer's patient guidance and inspiration.

I am also indebted to my husband for his encouragement and understanding and for the typing and photogramply 


\section{TABLE OF CONTENTS}

CIAPTIR

PAGE

I. THE PROBTEM AND ITS SCOPE .......... Introduction ................. 1

Statement of the Problem ........... 1

The Hypothesis............. 1

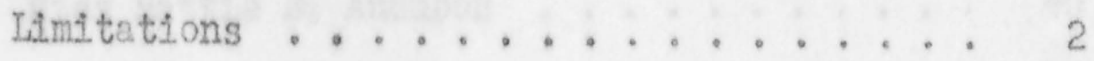

Method of Research ............ 2

organization of the Paper ........ 2

II. REVIEN OF THE LITLRATURE ON EARLY HISTORY

OF PRIVATE EDUCATION FOR GIRLS ....... 5

Introduction ................. 5

Colonial Heritage ............ 5

Barly Schools in the South ......... 9

Growth of Private Schools in Kentucky .... 12

Schools in Loulsville ......... 16

Analysis of Announcements ......... 21

Summary ............... 22

III. KEITUCKY HOME SCHDOL FIOM 1863 TO $1904 \ldots 24$

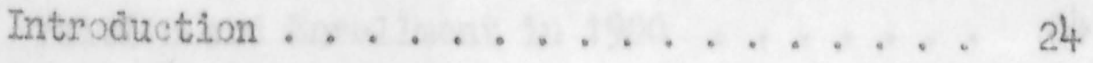

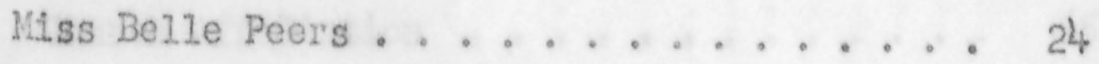

Kentucky Home School Founcied ....... 25

Msses Henrietta and Loulse Barbaroux . . . 27

Louisville after the War ......... 28

Belle Peers Alone Again .......... 29 
Teachers ............... 30

Course of study............. 35

Tuition ...................... 36

Scholars .............. 37

First Graduates ........... 38

Miss Hattie B. Audubon ........ 40

Tlrst Newspaper ........... 43

717 Third Avenue ............. 4

Changes in $1879 \ldots \ldots . \ldots 48$

The Faculty in 1879 . . . . . . 49

A Charter for Kentucky Home Seminary ... 51

Board of Directors ........... 53

No Telephone! .................. 54

The Southern Bxposition in $1883 \ldots 55$

Tornado of $1890 \ldots \ldots . . . . . .56$

The Eighties and Nineties ....... 56

Miss Jennie Benedict . . . . . . . 59

Conmencement .......... 60

The Course of Study after $1890 \ldots 62$

Tuition and Enrollment in $1900 \ldots 64$

Church Affiliation ......... 65

Ham ................ 69

Prominent Women ......... 70

Miss Peers, Pinclpal ........ 73 
IV. THE SCHOOL FROM 1904 TO $1908 \ldots 78$

Introduction ...............78

Beginning the Twentieth Century ..... 78

Ellen Scott Davison and Louise Preston Dodze. 79

Davison-Dodge School for Girls ...... 81

Course of Study ............ 83

Tuition ................ 86

The staff.................. 87

Class of $1905 \ldots \ldots . \ldots 7$

Davison-Dodge School sold ....... 87

Kentucky Home School Again ....... 88

Miss Calhoun's Curri vilum ........ 88

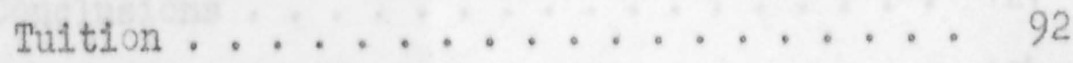

The shield .................. 93

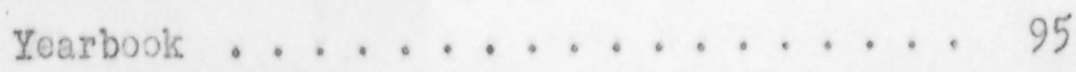

Calhoun Club ............... 95

the First Baseball Team . . . . . . 96

Miss Lella Calhoun ............ 97

V. KBNYUCKY HOME SCHOOL FROM 1910 TO $1913 \ldots 100$

Introduction .............. 100

Miss Annie Anderson ......... 100

Miss Annie Waters ........... 100

1220 Fourth Street ......... 103

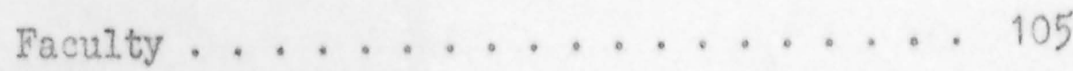


CHAPTER

vil.

PAGE

Course of Study ...................... 107

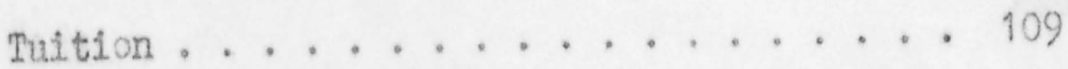

Alrs ........................... 110

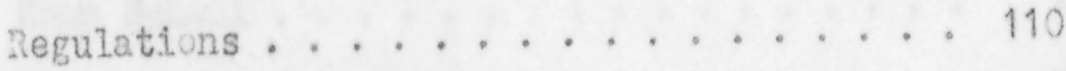

Belle Peers Scholarship Fund ....... 111

Mountain Fund . . . . . . . . 112

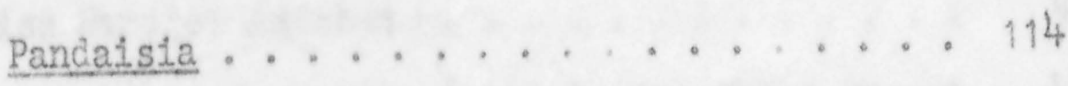

May queen ......................... 115

Commencement .................... 116

Kentucky Home School Continues ...... 116

VI. SUMMARY AND CONCLUSIONS ........... 119

Summary ................... 119

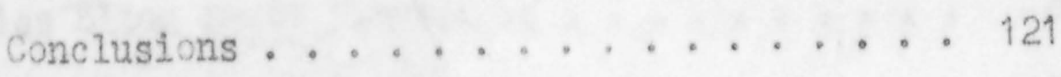

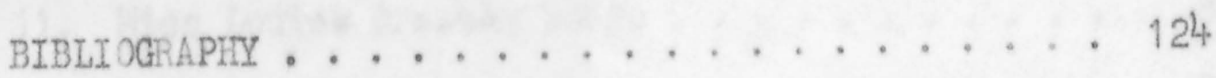




\section{IIST OF FIGURES}

FIGURE

1. Miss Belle Spencer Peers, Founder of Kentucky

Home school ................. 26

2. Noble Butler ............... 32

3. Miss Fannie Anderson ............... 34

4. Miss Harriet Audubon .......... 41

5. Home-School from 1880 to 1902, 717 Third Street 45

6. Miss Blien Whittier ......... 50

7. Seal of Kentucky Home School ....... 52

8. Home-School Boarding Students in 1890.... 58

9. The Right Reverend Thomas Underwood Dudley .. 68

10. Miss Bllen Scott Davison ........ 80

11. Miss Louise Preston Dodge ......... 80

12. 1220 Fourth Street ......... 82

13. Mrs. Peter Leldenger ......... 89

14. Academic Course in $1908 \ldots . \ldots 91$

15. College Preparatory Course in $1908 \ldots 91$

16. Kentucky Home School Shield ....... 94

17. Miss Annie Stuart Anderson ........ 101

18. Miss Annie S. Waters .......... 104

19. Academic Course in $1911 \ldots . . . . . .108$

20. College Preparatory Course in $1911 \ldots 108$ 



\section{CHAPTER I}

\section{TIE PROBLEM AID ITS SCOPE}

Introduction. Kentucky Home School for Girls, a private school for girls, has been in existence for nearly one hundred years and a written record of the school's contributions to the intellectual and moral education of girls in Louisville has never been compiled.

Because 1t has existed through periods of change it should have records and traditions. Too many years have already elapsed without an account of its contributions and time has destroyed some valuable information.

Statement of the Problem. It is the purpose of this study to compile an accurate history of Kentucky Home School for Girls Prom 1863, the date of Its beginning, to 1913. It will attempt (1) to show how the school has reflected the attitudes, traditions, and culture of Louisvilie; (2) to trace the development of the currlculum; (3) to determine the kind of students and faculty; (4) to present the methods of teachIng; (5) to ascertain its financtal support; and (6) to prosent itts philosophy of education.

The Hypothesis.s. The Kentucky Home School for Girls has been instructing girls for ninety-nine years. It has been an intellectual and cultural factor of the community contributing to the education and moral character of Louls- 
ville's young women through a "balanced development of the mind, the character, the emotional 11fe, and the physical health of its students." This work sets forth the fulfillment of these aims.

Limitations. The writton history is limited to the first fifty years of the school's operation. This is limited further to the records and other information which are available, since there has been no systematic compilation of the school's operation.

Method of Research. An exhaustive search has been made of the records of the school, University of Louisville Library, Louisville Free Public Library, and the Filson Club of Louisvilie. Records in the private possession of a.Jumae have been examined and students prior to 1913 were interviewed.

\section{Organization of the Paper. Chapter I briefly states} the problem, the hypothesis, and the methods and materlals to be used.

Chapter II gives a brief sumary of the history of private schools for girls.

Chapter III traces the operation of Kentucky Home School from its establishment in 1863 to 1904.

1

Bulletin of The Kentucky Home School for Girls, Inc. $1961-1962, p \cdot 2$. 
Chapter IV notes the changes made from 1904 to 1910. Chapter V shows its progress from 1910 to 1913.

Chapter VI Is a summary of this paper and states conclusions concerning the hypothesis. 


\section{CHAPTIRR II}

\section{REVIEW OF LITRRATURE ONT}

RARLI HISTORY OF PAIVAIE EDUCATION FOR GIRLS

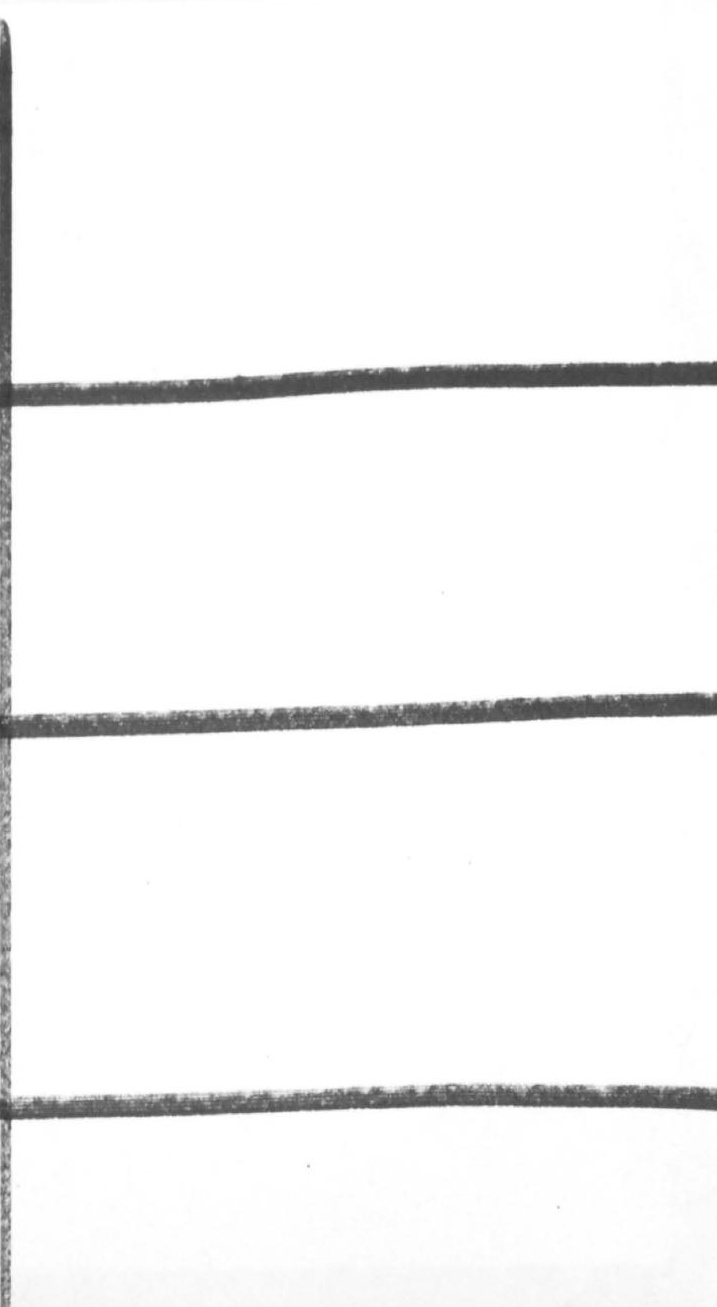




\section{REVIEW OF LITSRATURE ON}

\section{BARLY HISTORY OF PRIVATE EDUCATION FOR GIRLS}

Introduction. Chapter II sumarizes the development of private school education for girls in the United States, notes the struggle for the establishment of schools in Kentucky, and describes the beginning of education for girls In Louisvilie.

Colonial Heritage. American education owes much to the early colonists. They were deeply religlous and recognized that instruction was necessary to furnish the ability to read and participate in religious services, Teaching began as a home project and it always had a moral aspect. Clergymen would instruct the boys in the classics in order that they might enter one of the colleges that had been established. Then the "dame" school came into existence, for sevoral families would send their chlldren to one home to learn the rudiments of reading and writing. The girls were sometines taught knitting and sewing, but both boys and girls attended these schools. In the more populous communties the Latin grammar school required by the Massachusetts Law

\section{1}

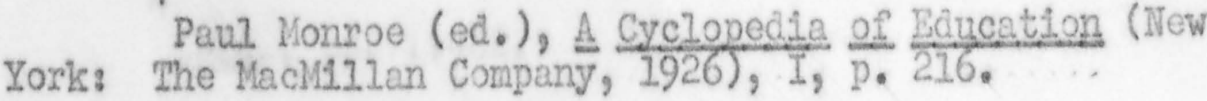


of 1647 came into being in order to prepare boys for college. These were the first secondary schools. They were patterned aitor the English model and played an important part in the educational system for a long time. Girls were not permitted to attend the Latin school because, generally, it was not thought necessary for girls to have any further education beyond the prinary level. However, private schools were established early in the seventeenth century. Information about Peter Burs, a schoolmaster of this pertod, says, "Enteries in Burr's account book indicate that he taught writing o.s well. as Latin, and that he admitted glrls, some of whom attended his school to learn lattin. ${ }^{3}$

A survey of school notices reveals that there were a hundred or more private schools established in Boston from 1700 to 1776. The majority accepted girls. The studies in all these schools were generally the same. Reading, writing, dancing, painting on glass, needlework, and frequently French were taught. The curriculum offered girls was not the same

\section{2} States (Itev York: Houghton Mifflin Company, $1919 \% \frac{\text { the }}{p_{0}} \frac{\text { Unit }}{29}$

\section{3} Boston (Cambridge: Harvard University Press, 1935), p. 8.

Robert Francis Seybolt, The Private School of Colonial 4 Ib1c., pp. 11-82. 
level as the program of study offered the boys in the Latin gramar school who were preparing for college.

Although the less densely settled communities probably had to accept for a teacher whatever person was avallable, and fortunately this was often a member of the clergy who was we1]. educated, in Boston "private school masters had to be approved and licensed by the selectmen."

Seybolt says that until the nineteenth century:

The public schools made no attempt to meet the educational neods of atl. They continued in the oldaccustomed ways. The private schools were free to originate, and to adapt their courses of Instruction to the interests of the students. The masters sought always to keep strictly abreast of the time, for the1r Iivelinhood depended on the suceess with which they met the needs. No such freedom or incentive was offered the masters of the public schools. It is quite evident that the private school was a flexible groving institut1 on which played an important part in the educational life of the town. 6

About the middle of the eighteenth century the acadeny developed. It was different from the Latin gramar school In that it admitted young people without reference to their previous accomplishments in any particular school unit. Candidates for the Iatin gramar school had to denonstrate their ablilties through examinations. The private girls' academies

5

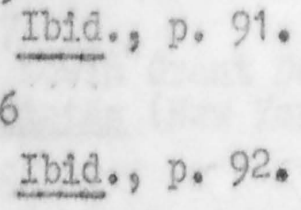


took acivantage of the girls' eagerness to learn and Included. geography, Inglish literature, rhetorlc, and Bible in thoir studies. After the beginning of the ninoteenth century, philosophy and other subjects whtch had been open only to boys were introduced.?

In the middle colonies many schools hed religtous affillations, and It was felt that boys and girls should have equal opportunities. The Qualkers wished tirt all children should have the same learning in order that they might be able to read the Holy Scriptures and to write and cast accounts. The Germans also had a rule that both boys and girls attend school. All could read but some girls could not write. The Moravians opened a boarding school for girls in Germantown, Pennsylvania in 1742 and another in Bethlehem, Pennsylvanta in 1749 .

The effect of the Revolutionary War was disastrous. Nost of the schools closed; however, the private pay schools were able to keep open longest. There was Increasing illiteracy and a decline in educational advantages. The new Federal Constitution made no mention of any form of education. By virtue of the Tenth Amendment, the control of schools and

7

Bdwin Grant Dexter, A History of Eaucation in the

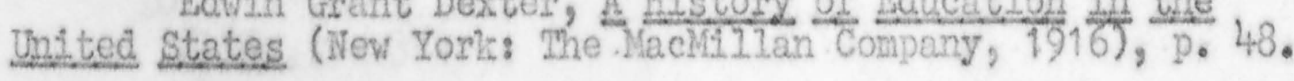
8 Cubberly, ap. cit., p. 83. 
education passed to the states. As soon as they had established systens of goverment, they attacked the problen of oducation. With the establishnent of public schools for girls as well as boys, the private schools decreased in number. However, some that were founded in the colonial period are sti1l flourishing.

Barly Schools in the South. Tho early settlers of Virginta, Georgia, and the Carolinas also recognized the inportance of an education. There were few children among the first settlers, but when orphan chllaren wore sent over schools were organized. These first schools were apprentice schools which taught "the rudiments of learning, the Christian religton, and some good trade." ${ }^{9}$ Indtan children were also given Instruction. Schools were founded to teach the seven to twelve year olds reading and the Christian religton. Beyond the age of twelve these children were taught a trade. As the colonies grew and prospered all those who could afford provided a tutor for their clilidren. Boys and girls received equal educational privileges in attending lessons, but since

\section{9}

Charles W1111am Dabnoy, Universal Bducation in the South (Chapel H411: The University of North Carolina PIess, 1936), p. 36 .

10

IDI. , p. 37. 
woman's mind was still constdered infertor to man and more emphasts was placed on a women's social accomplishments, their studies differed, The girls were generally oxposed to roading, writing, and simple arithmetic in addition to music and dencing.

About the middle of the eighteenth century schools of private masters and mistresses beceme prominent. Toward the end of this century there were a number of these academies. There wore those of the local nature which were modest though capable of supplying the educational needs of the conumities. Schools of this type vere frequently called "old fleld schools, "hedge schools," on "forest schools," As the population increased the more substant1211y established ones sought Incorporation by logislative enactment. Another type of academy was more pretentious and had wider patronage. It had mone creditable equipment and often had an endownent, 0.17 of which enabled it to extend its usefulness. Many recelved chartors from the stnte. Theis reputation was gatned because of excellence and thoroughness of work, and they prepared numerous students for college. Academfes were usually privately controlled on managed by the incorporated board of trustees. The curriculur of the academy was somewhat broader than

11

Thonas Woody, A History of Women's Bducation in the United States (Now York: The Science Press, 1929), D. 271 . 
the Latin gramar school, because it was intended not only for those who were golng to college but also for those who were destrous of more oducation than the locel. school offer12 ed, English gramar, Latin, Greek, Fronch, writing, arithmetic, bookkeopling, geography, algebra, geometry, and natural. philosophy were among the subjects studied. ${ }^{13}$ Both boys and girls attended the academies, but reading, writing, and spellIng were the only subjects required of the girls. Lating French, misic, pointing, and needlework were elective. "An effort was made to combine interest in good reading with moral training." 14

The builaings were usually wood, sometimes brick.

Blackboards were rare and school furniture unknown.

\section{Edgar W. Knight says:}

The teachers vere often well equipped for their work though few, if any, of the earliter ones vere trained professiono.11y. Discipline was usually rigid and instruction was remarkably thorough and not infrequently advanced for the time. In not a few cases, students in some academios were adequately prepared for the junior year in the loading coiloges of the country. The remuneration re-

12

Edgar W. Knight (ed.), A Documentary. History of Education in the South Before 1860 (Chapel Hil7.: Univorsity of North Carolina Pross, 1953), Vol. IV, p. 16.

13

Woody, a․ citt., p. 296.

14

Knight, on. citt., p. 53. 
celved by the teachers varied greatly: . . Frot the evidence at hand it would appeor that mony of them were well paid.15

The southern academy differed little from the private school. In the North except that it existed longer in the South, although in the South nore emphasis was placed on the "soclal. graces" and various forms of needlework and painting.

Growth of Private Schools In Kentucky. Kentucky was originally part of Virginia, so her growth and development are closely related to Virginia's advancement. The Virginia colonists firmly believed that education should be a private endeavor. The early settlers of Kentucky had a bitter struggle over land ownership. They eeme from a variety of origins but all were seeking to establish homes and make a. living by developing the country. There was class antagonism caused by the extensive land speculation and Insecure titles to the land. The people vere disturbed socially and economically. "The main stream of the peoples' lives was untouched by any plan of education." In addition, many of the settlers believed that the children would profit more fron everyday tasks neces-

15 Ibic.., p. 54 . 16

Frank L. McVey, The Gates Onen Slowly. (Jexington: University of Kentucky Press, 1949), p. 9 .

17 Ibid., p. 11. 
sary for existence than they would from books.

The first school was a private school established in 18

Harrodsburg in 1776. Mrs. Jane Cones, wife of one of the earliest settlers, was its teacher. The next year a school was established at McAgee's Station and other's followed, These were "old fleld" or "heägerow" schools. " other schools or academies which wore conducted for boys were mainly in and about cities. About twenty-five years elansed before schools for young ladies were established and then they offered only spelling, reading, and needlework.

The beginning of education in Kentucky was through the efforts of Caleb Wallace, a Virginfan, who believed in universal education which was known at this time to be only by academies and colloges. Wallace, after taking an active part in establishing colleges and acadenies in Virginia, came to Kentucky, then a district of Virginia, in 1782. In 1783, as a member of the Virginia General Asserbly, Wallace secured a. b111 for founding Transylvania Academy which later became Transylvania University. He plamed the earliest system of education in Kentucky by trylng to establish schools in a.1. the centers of population. Finally an act was passed endow-

18 Nonroe, ap. cit., p. 591

19 Dexter, op. stt., p. 125 
Ing an acadony in each county with six thousand acres of pub11. land. Trustees vere appointed from among the prominent citizens. They were to take charge of the grants, build schoolhouses and make courses of study in accordance with the needs and wishes of the people.

The academies that were established were public but not free because they generally charged tuition. They varied greatly because there was no supervision or central trustees. The academies were poorly administered. The fund created from the sales of the land soon dwindled because of bad management.

Since the public academies of the later eighteenth and early nineteenth centuries had failed, a legislative act in 1825 favored the establishment of private schools. Five or more persons of a community could acquire a small amount of land, erect a building, employ a teacher, and thereby estabIish a private school. The legisiature chartered these private schools in the same manner as it had chartered the pubIic academies. There were 230 private acaderies established In Kentucky from 1810 to 1890. A board of trustees managed the private academy. Private academies were generally established as secondary schools, but there was an elementary department in nearly all of them. Frequently the public school district contracted with the private acadomies to have children of the district taught there. The academy would 
then recelve the public school funds allocated to the district. With the advent of state laws for public education in 1870 the role of the private school in elementary education diminished, and it becane largely a school for instruction on a secondary level.

There were academies for girls and academies for both boys and girls. Many of the academies for girls were boardIng schools. One of these early boarding schools for girls was the Greenville Institute at Farrodsburg. It is interesting to note the subjects that generally had not been taught before in girls' schools; such as primery physiology, botany, zoology, algebra, geometry, natural philosophy, Paley's natural theology, Constitution and Laws of the United States, astronomy, geology, and logic. Latin, Greek, and mathematics were offered for those who wanted to pursue their studies in college. 21 Catalogues and other records indicate that changes were being made in the curriculum of private academies. Some subjects were dropped, others were added, but some remained. Even at this early period programs of study vere changed to

\section{0}

Hoses Edvard Ligon, A Astory of Public Education in Kentucky, Bulletin of the Bureau of School Service, June $1942, \mathrm{pp} .39-44$.

21

$$
\text { Ioid., p. } 48 \text {. }
$$


meet the economic, social, and professionol needs of the peom 22 ple.

Some private academies were owned and controlled by roligious denominations, The Presbyterions, Baptists, Methodists, and Christians as well as the Roman Catholic churches ostablished schools, In some cormunities private stook comm panies were organized to operate the schools. In other localities private individuals, usually well-known teachers, owned and directed the schools.

Private acadomies charged tuition, so only children from the higher economic levels could attend. It was during the pertod from 1850 to 1880 that private schools contributed most to education. 23

Schools in Loutsville. The first school in Ioutsville was a log school house built inside the fort next to Twelfth Street Church at Main and Twelfth Streets. It had a board roos and puncheon floor and was completed in 1783. George Leoch, "an Inglishman of fine culture, who had been educated for the Bpiscopal miristry, ${ }^{24}$ was engaged to teach the boys

22

Ibid.

23

Ibi.d.

24. Stoddard Johnston (ed.), Memorial History of Louisvil1e (Chicago and New York: American Biographical Publishing Co., 1896) I, p. 52. 
and girls. "It was a high school class in which the Classics were taught as well as English studies."

In the immediate years that followed there were fow schools that admitted girls and these were poor. The log building as well as the course of study was rather primitive. The teachers were paid in tobacco or other produce. Reading, writing, and "ciphering to the rule of three" were taught. 111 studying was done aloud. By 1816 there were a number of schools of this type in Louisville. Tuition was $\$ 2.50$ per quarter. These schools were of great service to the oducation of girls at that time, since otherwise they would have been neglected.

Few sources of information exist about the schools of Louisville in the early nineteenth century. The newspapers which supply most of the data are in poor condition and many issues are missing. Notices announced the opening of the Louisville Acadeny for Female Education on Juzy 14, 1813. A Mr. and Mrs. Green were the founders of this boardIng school, and their philosophy of education is expressed in the following statement:

Being well avare that knowledge is more readily

25

$$
\text { Ibic., p. } 52 \text {. }
$$

26

Florence M. Wolff, "A Study of Girls Schools in Louisville Prior to $1900^{\prime \prime}$ (unpublished professional paper, The University of Loulsvilie, Louisville, 1951), p. 13. 
Imbibed by the young minds when accompanied by a gentle rather than a harsh mode of treatment, it will be their aim to conciliate the affections of their pupils and . . render the attainment of Knowledge an easy and delightful. employment. 27

Reading, writing, aritlmetic, gramer, composition, geography, and music were taught at the Greens' school. Another boarding school, Mrs. Jett's Female Academy, opened In 1814. The curriculum of this school mentions, in addition to the subjects taught at Greens', history, geography with the use of globes, French, painting, and drawing. The Greens' offered board and tuition for $\$ 100.00$ a year for the regular course, with music extra. Mrs. Jett charged $\$ 150.00$. At both these boarding schools the girls had to "find their own beds, \&c." The Mann Butler Academy, a day school, was founded in 1816. Tuition was $\$ 32.00$ a year. A year Jater Miss Mary Ann Silliman's School for Young Ladies was opened. The curriculum mentions "Spelling, the use of the Globes, and Needle Work in its various branches." ${ }^{29}$ Tuition to Miss Silliman's was $\$ 15.00$ per session for the common branches and $\$ 20.00$ for the higher ones. Nothing is known of the number of students in each school or the span of the school's

\section{7}

$$
\text { Ibic., p. } 15 .
$$

28 Ib1d., pp. 14-15.

29

\section{IbId.}


existence.

In the $1830^{\circ} \mathrm{s}$ a number of announcements of girls' schools appeared in the papers. Sone were a few 1 ines headed "A Card" while others were more elaborate and lengthy. A brief notice in The Loutsvilie Daily Focus of 1831 states that Miss BIizabeth Blliot proposes to open a School for little Misses and Young Ladies, in which will be taught the English and French Janguages, Painting, \&c." ${ }^{30} \mathrm{AMr}$, and Mrs. F. Cosby, Jr. advertised that they would "re-open their School for Young Ladies . . at their present resjdence on Jefferson Street" with terms of tuition the same as those of the last session." ${ }^{31}$ This same year Miss Annah M. Bwell opened the Louisv113e Acadeny for Young Ladjes "at her residence on 2nd street, second buflding South of Jefferson." The tuition was \$10.00 per session for Orthography, Reading, and Writing: \$15.00 for Geography, Arithmetic, Grammar History, Botany, Chemistry, Natural. Philosophy Including Astronomy and Globes; and \$1.0.00 extra for Drawing and Painting. Young ladies courd board with the family of the Principal for $\$ 55.00$ a. session, consisting of 22 weeks. ${ }^{33}$ This is the most ambi-

30 The Ioufsvinte Do:17y Eocus, Aug. 10, 1831. 31. Loutsvizie Deiny Eocus, Aus. 11, 1831. 32 Ibid., August 29, 1831.

33 Ibid. 
tious curriculum annoumced up to this time and the first of the Louisvilie academies to mention any of the natural sciences.

About 1838 Mrs. Susan B. Thornton must have begun a school for young ladies, for The Louisvill?e Da17y Eocus of October 6, 1841 amounces the opening of 1ts Fourth Term. This was a boarding school located "three niles on Bardstown turnpike. ${ }^{34}$ The charge for tuition and board was $\$ 75.00$, but French, Latin and music were extra.

Sometime prior to 184 a $\mathrm{Mr}$. B. Hyde had established a boys' school on Centre Street, and in 184? a Female Depart-ment was adied under the direction of Mrs. Hyde. ${ }^{35}$ Two other schools were oponed about this time; Atkinson High School on Green Street between First and Second under the direction of 36 Rev. J. Atkinson and Lady, and Mrs. Eliza Fleld's School which was on 4th between Broadway and Breckenridge. Records show that the Atikinson's Schoo? existed at least until 1865 and Mrs. Fie?d's School. disbanded In the early 1860's. Although no further information can be obtained about the school,

34

Louisville Daily Gazette, October 6, 1841. 35 IbId. 36 Ibic. 
Rev. Chas. H. Page who taught a Female sominary on 5 th street between Chestnut and Walnut stated in a newspaper announcement that he had ongaged a Mons. L. Plcot, a native of France.

In 1852 a group of men founded Albion Fenale Collegiate Institute consisting of a Primary, a Gramar, and a Seminary Department. It became Louisville Female Seminary by a legislative charter in Fobruary, 1854. By 1890 the school had moved to Newcomb Place near 2nd and Broadway, and $\mathrm{Mr}$. and Mrs. W. B. Nold were succeeded by Miss Annfe F. Nold as Principal. Their philosophy of education is explained in the following:

Education consists in the development of the whole being, and it is our delight to mingle with our pupils and to watch their progress, impressing upon their minds the great truth that one's education ends only' with life on earth, which life, if well spent, will lead to a glorious life on earth, which life, if well spent, will lead to a glorlous life in Heaven.38

Analysis of Announcerents. Many of the announcoments stress the competence of the teachers, such as: "a native French teacher, inferior to none in the West." 39 or Mrs. Thornton's "highly competent assistant, a young lady from

\section{7}

Ib1d.

38 Prospectus, p. 19.

Pamphlet, Loulsville Fomale Seminary, 39th Annuel 39 Louisvil1e Daily Gazette, Oct. 6, 1841. 
40

Virginia." This would suggest that great effort was made to achieve high teaching standards.

The various curricula show the increasingly broadenIng fields of instruction for women and the inclusion of science and mathematics in their programs of study.

The growth and expansion of Louisville is suggested. by the location of the schools. The first school was at Twelfth and Main Streets. By the 1830's the center of education appears to have moved to the vicinity of second and Jefferson streets. Schools were found on Broadway by the mid-nineteenth century.

Sumary. Chapter II is a brief picture of education for girls from the founding of the colonies to 1850 with a more detalled treatment of private schools for girls in Kentucky and especially Louisville. The descriptions of faculty and curricula have shown concern for high standards of morality and scholarship, with a gradually broadoning curriculum.

40

Ibid., Apri1 9, 1841. 

Introduction. The primary classes which Miss Belle Peers started in 1863 have grown to be a school of over two hundred girls which has existed nearly one hundred years. This chapter will describe its beginning and continuation under her guidance.

Miss Belle Peers. Although the date of the founding of Kentucky Home School was uncertain, the founder and its purpose are very certain. Miss Belle, as she was addressed, was the daughter of the Reverend Benjamin Peers. He was an Episcopal clergyman but also a key figure in the establishment of schools in Kentucky. Dabney says, "The most advanced thinker on this question of public education and the greatest worker for schools in this period in Kentucky was Benjamin Orrs Peers." ${ }^{1}$ His teachings were similar to those of his contenporary, Horace Mann.

Arabella Spencer Peers was born in Lexington, Kentucky In 1832 and a year or two later moved to Louisville where her father became rector of St. Paul's Church and established.

\section{1}

Charles William Dabney, Universal Education in the South (Chapel Hill: The University of North Carolina Press, 1936), p. 269. 
a select school for boys. Unfortunately, The Reverend Mr. peers died before her eleventh birthday. She lived with an aunt and uncle briefly and then went to St. Mary's Hall at Burlington, New Jersey, After she was graduated at sixteen, she returned to Louisville to make her home.

When she was about twenty-two Miss Peers began teachIng in Mrs. Bliza. Field's School where she had charge of the primary department.

Kentucky Home School Founded. For many years the date of founding was established as 1865 and was thought to be accurate as late as 1915 . $^{2}$ However, Miss Annie Stuart Anderson, principal from 1910 to 1945 and a student of Kentucky history, established the date of founding as 1863 .

In September, 1863, twelve little children gathered together in a room over the vestry of Christ Church formed a primary class. Al1 unconsciously they became the cornerstone of a school that was to be an intellectual factor in the community for more than half a century, and down to the present time. In their dress of the 1860 's, they seem quaint little children; maybe they were prim; we know they loved their teacher.4

\section{2} 1915), p. 3.

3 Piles, n. đ..).

Annie Stuart Anderson, "Notes" (Kentucky Home School

4

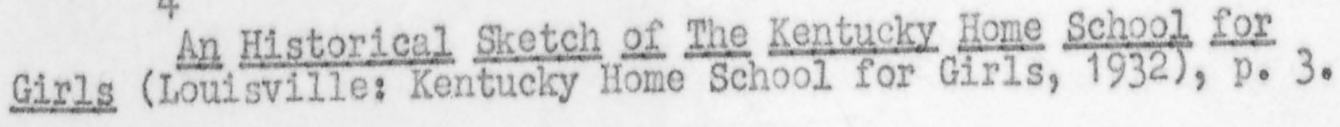




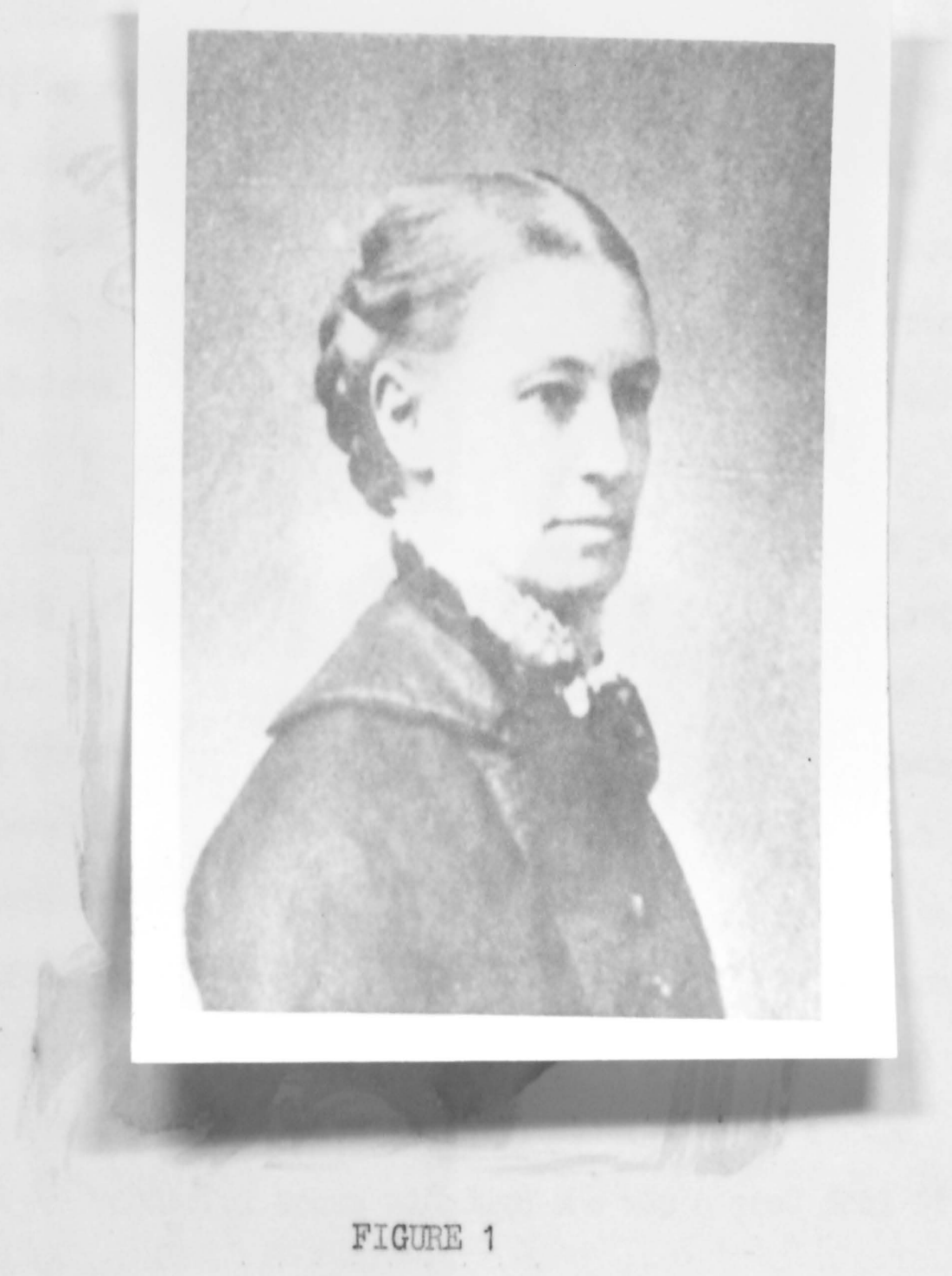

\section{Miss Belle Spencer Peers}

Founder of Kentucky Home School 
Miss Belle's school prospered and larger quarters were needed, so she moved her classes to Mrs. Field's School on Fourth Street, south of Broadway, behind Warren Memorial Presbyterian Church. She taught her girls in the same room where Mrs. Field was instructing her students. This arrangement obviously was unsatisfactory and lasted only one year, 1867.

Misses Henrietta and Louise Barbaroux. The same year that Miss Belle began primary classes, 1863, Miss Henrietta and Miss Loulse Barbaroux opened a school at Seventh and Walnut Streets. It included a junior and senior department. Miss Kate Barbaroux, their niece, told Miss Anderson that Henrietta took care of many Confederate refugees in the basement of her home and also gave refuge to several Confederate soldiers. "Miss Henrietta was a woman of great energy and common sense and excoutive ability, cheerfulness, a good. manager-a wonderful woman although she was a good deal of a rolling stone." 7

Schools Combined. In 1868 Miss Belle and Miss Henrietta

5

Anderson, on. cit.

6

The Louisvi17e Da11y Journal, August 18, 1863.

7 Anderson, ap. cit. 
combined their schools and for three years taught together in Miss Henrietta's school house at 12 East Chestnut Street. It was a two story building in the rear of two houses owned by Miss Henrietta's mother, Mrs. Joseph Barbarowx. Miss Fannie Anderson who began teaching in the Misses Peers and Barbaroux school in 1870 sald that The Reverend Mr. S. A. Scearce, assistant minister of Christ Church, who taught Latin, and Mrs. pelot, who taught writing were the only other teachers.

Louisville after the War. Louisvilie was one of the few cities of the South to emerge from the war more prosperous than when it had begun. It was a transfer point by reason of its position at the falls of the ohio. In addition, some farsighted merchants had promoted the building of a railroad that reached into the heart of the South, thus realizing a profitable income from both the North and the South.

These prosperous citizens had built spacious homes on large lots along Chestnut and Walnut Streets and the avenues between Second and Seventh. Most streets north of Broadway and between Preston and Bighteenth Streets had been paved and the sidewalks bricked. At night the lamplighter would. make his rounds to 11ght the gas lights that 1lluminated the streets. The homes were extravagantly furnishod with beauti- 
ful furniture and fine damasic and brocade araperies. Louisville was known throughout the South for the hospltality of its homes. Visitors from out of town were entertained with elaborate house parties and there were gala balls at the Loulsville Hotel and the Galt House, rebullt at a cost of more than a million dollars. In 1873 Macauley's Theatre was opened and for the next fifty years it was the pride of Louisville. Here Louisville's own Mary Anderson, at sixteen, made her debut in "Roneo and Juliet" in 1875, and other famous actresses and actors; Sarah Bernhardt, Madame Modjeska, Lily Langtry, the Drew family, the Booths, and Joseph Jeffer son played before 1ts audiences. This was the beginning of "a golden age ... of high standards of living, of great civic improvements and of peace and tranquility which allowed time to pursue a lively interest in the arts and great attention to the social amenities."

Belle Peers Alone Again. This was the Louisville scene when, in 1871, Miss Henrietta continued alone the school she and Miss Peers had together, and Miss Belle took a house at 209 second Street. It is said the roason for Miss Belle's

\section{9} City (New York: Julian Messnor, Inc. 1946), p. 216 . 10 of Louisvilie, 1961), p. 46. 
leaving Miss Berbaroux was to make a home for her aunt who had taken care of her after the Reverend Peers' death. Miss Fannie Anderson and Mrs. Pelot went with Miss Belle, and Noble Butler, a former professor of ancient languages at 11 Loulsville College, joined the stafe to teach elocution and literature. From 1872 to 1874 the school was located at 208 Third Avenue and then moved to 13 West Chestnut Street. Here Lt was surrounded by stately residences on a lovely treearched street. The house later became the home of Henry 12

Watterson, the famous editor.

Teachers. "There were few changes, from year to year,

in the faculty. Then, as now, the stabillty and excellence of the faculty was characteristic of the school. "

"For a decade, of the faculty, teaching elocution and literature, was Noble Butler, whose Practical and Critical Grammar of the Enclish Language, and Practical Grammar of the

11

3. Stoddard Johnston (ed, ), Memorial History of Louisvi11e (Chicago: American Biographical Publishing Company, 1096, p. 235 .

12 Girls (Iouldsville: Kentucky Home School for Girls, $\frac{\text { An }}{1932)} \frac{\text { Historical }}{\text { p.5. }}$. 13 Girls, $10 \mathrm{An}$. Historicel Sketch of The Kentuclsy Home School for 
Eng7ish Language are among the small. number of monumental

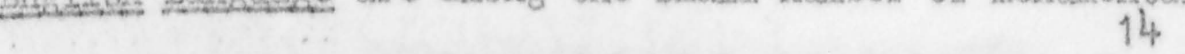
works upon gramar collected by Columbia University." Dr. Butler's texts were, no doubt, used at Home-School for they 15 were in use in the Louisville Public Schools. Noble Butler was listed as a teacher in the Home-School for Girls Bulletin for the year 1881-1882; therefore, one would conclude that he taught up until the time of his death, Fobruary 13, 1882. "As the cortege went from his home at 152 Walnut street, and then down Chestnut Street to Third, Miss Belle Peers Home School pupils joined in and followed in procession to the Cathederal in a body." He was respected for his eminent scholarship, profound thoughts, and devotion to teaching, and he was admired for a gentle manner and pleasant personality. Nary Anderson, who was a pupil of Noble Butler but not a

14

\section{IbIC.}

15

Blizabeth Humel, "Noble Butler: Louisv1lle Educator and Author" (unpublished Master's thesis, University of Louisvilie, Louisvilie, 1962), p. 98.

16

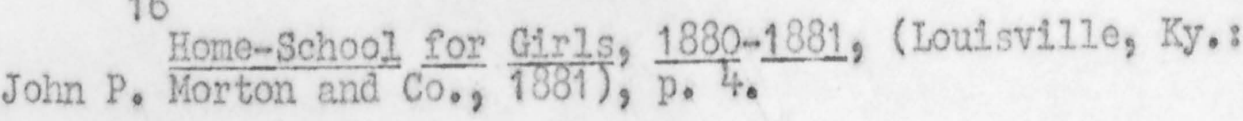

17 Fumel, op. cit., p. 95 .

18 Ibid. 19 Ibid. p. 100. 


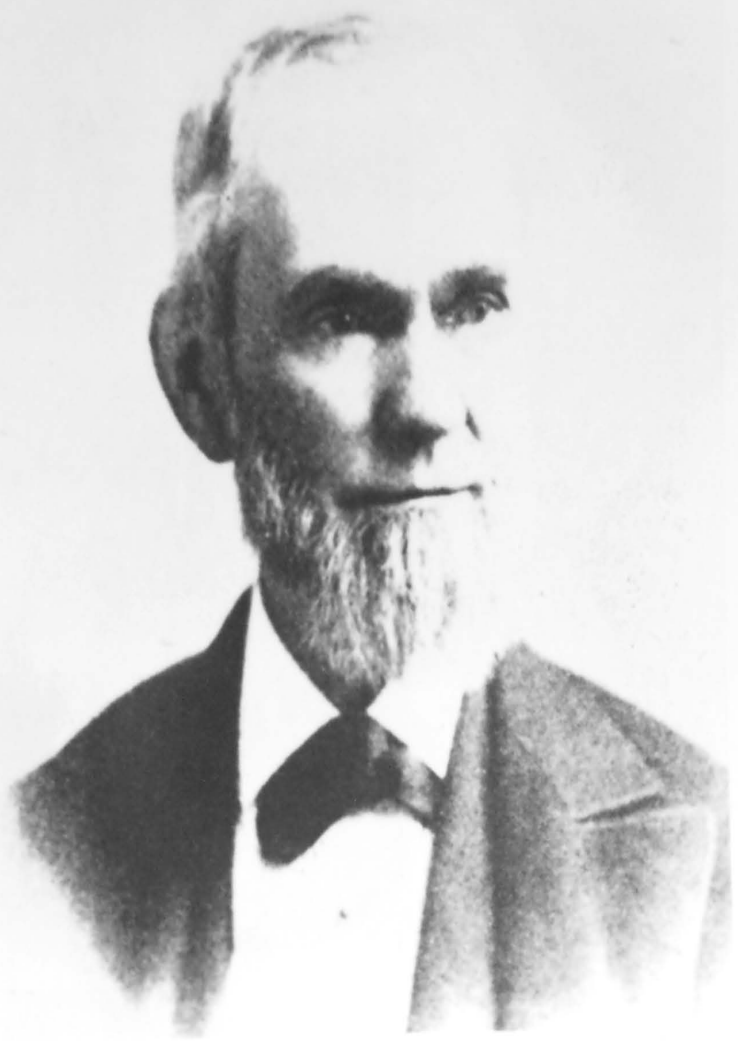

FIGURE 2

Noble Butler 
student at Miss Peers' school said,

He was an extraordinary man, very gentle orderly" and thorough. I knew him when I was a very young girl, and had my first lessons in English Ifterature from him. I remember so well his enthusiasm ovor the subject when we began reading Chaucer together. He was one of the most adequate men I ever knew in his subject ...

- A All he explained to me, and the vistas he opened out to me in pootry and prose are as clearly mine today, as they were when he gave thom to me.20

There is a reference to him later in a quotation from the School Bel1.

Miss Fannie Anderson had been a pupil of Miss Belle's when she was teaching at Mrs. Flelds' school and she returned to Miss Belle as one of her faculty in 1870. She taught mathematics unt11 1893. "Miss Fannie Anderson's staunch and colorful personality had inspired admiration and devoted affection-or awe in the heart of those not gifted in matheme21

tics." Miss Henrietta Gray remembers Miss Fannie's having quite a temper and throwing books at students who misbehaved or didn't study lessons.

Mrs. S. Pelot taught penmanship for more than thirty years, and although she was responsible for the Spencertan hand of many of Loulsville's young ladies, little else is

20

Pancaista, op. cit., p. 13.

21

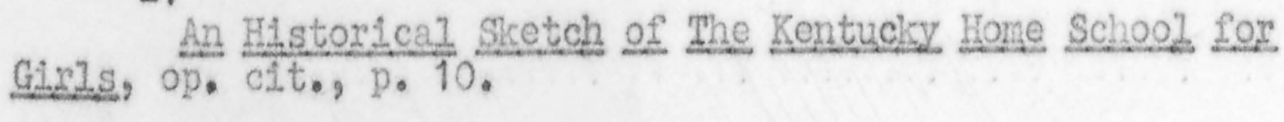




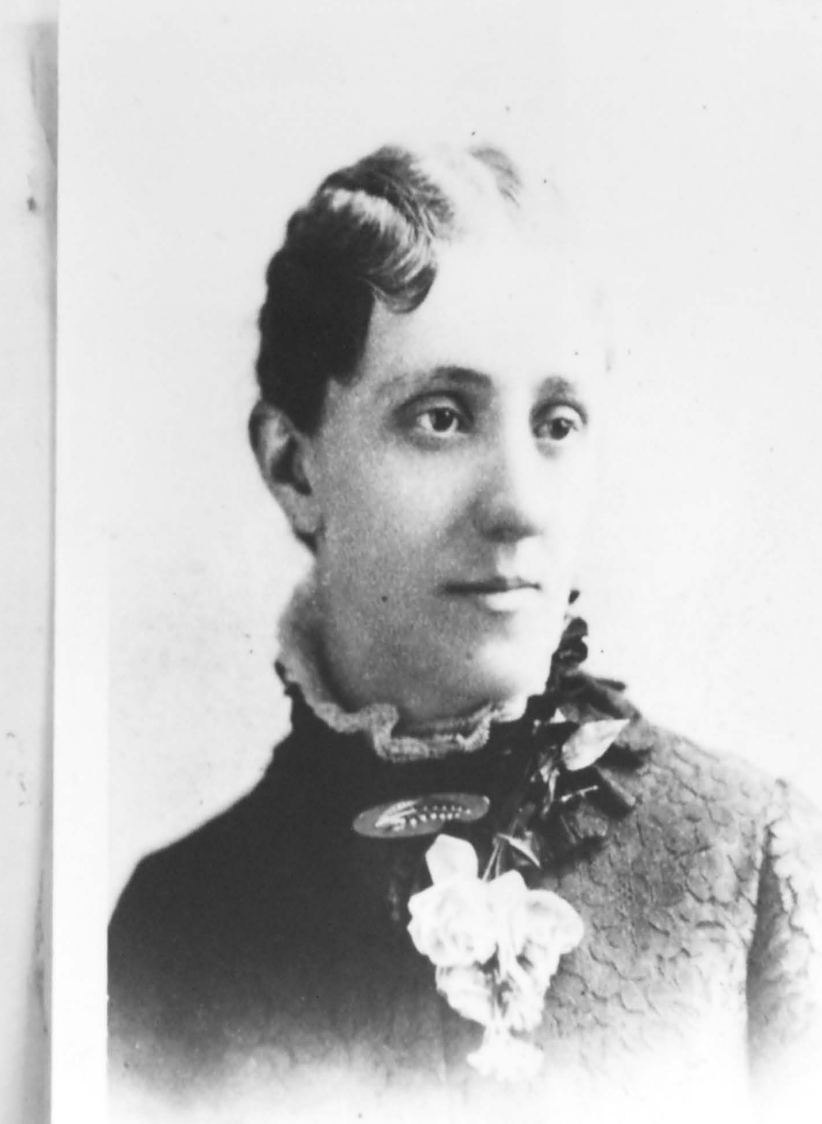

FIGURE 3

Miss Fannie Ande son 
known of her.

Course of Study. The earliest Bullotin avallable announces the school year beginning September 7, 1875 and ending June 16, 1876. The following Course of Study was 1isted:

The Course of Study includes a Prinary Dopartment; a Juntor, a Midale, and a Senior Class. Bach Class is divided Into two sections, $A$ and $B$; a section occupying a full year.

\section{PRIVARY DEPARTIENIT}

Spelling,
Writing, Geading,
The Blementary Ruzes and Tables in Arithretic.

\section{JUNIOR CLASS}

Spelling,

Writing,

Mental Arithretic,

Geography,

Composition Exercises,

\section{MIDDIR CLASS}

$\begin{array}{ll}\text { Spelling, } & \text { Reading, } \\ \text { Writing, } & \text { Arithretic (finished and } \\ \text { Algebra, } & \text { reviewed), } \\ \text { Botany, } & \text { yythology, } \\ \text { History, } & \text { Natural Philosophy, } \\ \text { Rhetoric, } & \text { Composition, } \\ \text { Gramuar with Annlysis. } & \end{array}$

\section{STITOR CLASS}

Spelling,

Writing,

History,

Algebra,

Chemistry,

Natural. Hilstory,
Reading, English Literature, Astronomy,

Geometry, Mental and Moral Philosophy, Composition.

22. ville: John P. Korton and Company, $\frac{\text { Kentucisy }}{1399}, \frac{1898-1892}{\text { D. }}$, (Louis- 
Applicants are admittod Into the Prinary Department without examination, at any age. Aümission to any of the other clesses is granted to such only as sustain an examination in the studies which precode it.

A diploma w111 be given to those who complete the course of study.

There are two testinonials of standing, or first and second honor, given at the close of the year to all whose records reach a fixed standard; and a gold medal for highest excellence in Mathematics.

The Princlpal's gold medal is given for punctual attendance and highest average in deportment and lessons.

The names of those who have not recelved a discreditm mark during the year w111 be placed on the roll of honor. Arrangemonts are inaking for giving in Physical and Natural Science and Philosophy by a system of lectures. The lecturers engaged are entnent in their specialties.23

Instruction in French, Gorman, and latin was offered for an 24

additional fee.

Tultion. The first printed record of tuition is in the Bulletin for the $1875-1876$ school year.

\section{TERMS PER YEAR}

\section{Payable Semi-annually in Advance}

Primary and Junior Clesses, . . . \$60.00

Midàlo and Senfor Classes, . . 80.00

French, . . . . . . . 25.00

Geman, . . . . . . . 25.00

Latin, : $\therefore$. 10.00

Board, including Washing, Fuel, lifhts, and Tuition in Bnglish Course . 340.00 Music at Teacher's Prices

only a limited number of boarders can be accomodated.

\section{3}

Home-School for Gir]s, Bulletin for school year. 1875-1876, (Louisvilie, Ky.: John P. Morton and Company, n. ..), pp. 9-10,

24 Ibid., p. 11 . 
Puptils will be received at any time during the Session, but no deduction w117 be made for those who leave before the close of the term, except by special agreement. In case of protracted absence (not less than $51 \mathrm{x}$ weeks) caused by sickness the loss will be divided.25 Scholars. "The Kentucly liome School had its origin in

a class of twelve children" and by 1866, three yoors later, there were thirty girls. Within the next ton yoars this group had grown considerably, for there were now ninety-oight. Kost of the girls were from Louisvinle or Jefferson County; however, there were "scholars" from Mississippi, Paduch, Neade County and B11zabethtown. The latter were probably boarding students, and some of the Jefferson County lasses may have also been boarders, depending on the section of the county in which they lived. Commication in the eighteenseventies was not quite as rapid as it is today. Several hours ride in a horse and carriage was not only time consuming but quite arduous. Unzess the ginls lived close to the city limits or near the railroad which ran to lexington, they boarded with Miss Belle. Louisville had established a public school system but beyond its limits the children had to attend private schools or study with a tutor. Among the list of students

\section{5}

\section{Ibid.}

26

An Historical History, op. cit., p. 3.

27 vilie, Ky.: John P. Morton and Company, n.d.), pp. 5-8. 
one can find the names of many well known fomflies who had contributed much to the communty and who in succeeding years were influential in the progress of Louisvinie. Included in the names were Anderson, Barret, Ballard, Brandeis, Buchanan, Casseday, Cochran, Galt, Haldemen, Hite, Kennedy, Shallcross and others.

Erst Graduates. The first class vas graduated in 1876; there were two graduates, Nellie Cunningham and Ifllie $\mathbb{Z}$. Stucky. Among the treasured possessions of the school is a composition book belonging "to the principalship of Miss Bell Reers. It contalns copies of many Salutatories and Valedictorles from 1876 (the date of the first greduating class) to 28

June 1885." For many years these were read at commencement, and it was considered such a relief when Miss Belle discontinued the practice. Each girl's address is written in hey own handwriting; the thin, spidery script common to this period. The letters, for the most part, aro well formed, but some make unconventional detouns, making the words almost 11legible. The ink is now odd shades of purple and brown. The language is flowery, often eloquent, and the thoughts fre-

\section{8}

"Salutatory and Valedictory Lssays, 1876-1885," Kentucly Home Bchool files, n.p., n.d,).

29 Anderson, op. cit. 
quently intellectud. Nellie Cunningham wrote the first entry, "Iloquence" which states, "Sloquence has been the means of leading soldiers to victory and triumph . . It has convicted the Infidol ... gave rise to the Crusades . . . enabled an orator of more modern times to achifore much in the cause of his country . . saved the new Republic (France) from an Imediate return to the reign of terror." ${ }^{30}$ In a later Salutatory entitled "Clothing," Emily Kennedy speaks of nature's clothing; the clothing that covers the body; and lastly, the expressions in which man dresses his face. "If you wish to make your face so beautiful that even little children shall be attracted to you . . . you rust clothe your heart in a dress of Charity, trimmed with the pearls of Hope, and fastenings of Faith." ${ }^{31}$ Many of the thoughts are reminiscences of school days and anticlpations of the future such as these:

To you my classmates, it is hard to say goodbye, for $1 \mathrm{f}^{\mathrm{I}}$ were not bound to each of you by much closer ties, constant association might render it hard to break the chains by which similar hopes and aims have unfted us during our social life. Together we have studied and played and dreamed of the future which looks so bright. Here-to-for, we have had smooth salling, ... we have had others to think for us, and to

30

og. cit.

"Salutatory and Valedictory Bssays, 1876-1885," 
advise us, but tonight as we bid farewell to our schoollife we enter the arena where we shall have to think ond act for ourselves, among trials of which we are now ignorant. Our trajning here has been a fit proparation for the future, and if we live up to the principles here inculcated, not less by example than by words, we can stray from the path where sorrow is known. 32

These vere the thoughts of Mamie A. Pettet in 1878.

\section{Miss Eattie B. Audubon. Sometime prior to 1874, Miss}

Harriet Audubon, granddaughter of the fomous ornithologist, had joined the faculty to teach Iatin, German, and music. Miss Henrictta Gray says that Miss Hattie was a wonderful person with great integrity. Kiss Gray once asked her if she ever told a falsehood. Miss Hattie replied, "Yes, Once," When she became a septuagenarian and no longer taught regular classes, she typed manuscripts at home. One afternoon she was copying a rather long and tedious manuscript and had almost completed it when several. ladies came to call. She was summoned from her work and when she greeted then she told. thom how glad she was to see them. She related to Miss Gray that this was not the truth because she vasn't glad to see them since she really wanted to complete the typtng.

Miss Hattie was a very active person. She did not believe in being idle. Whenever she rode on the streetcar

32 Ibid.

33 1875-1876, Hone-School for Gir1s, Buzletin for school year 


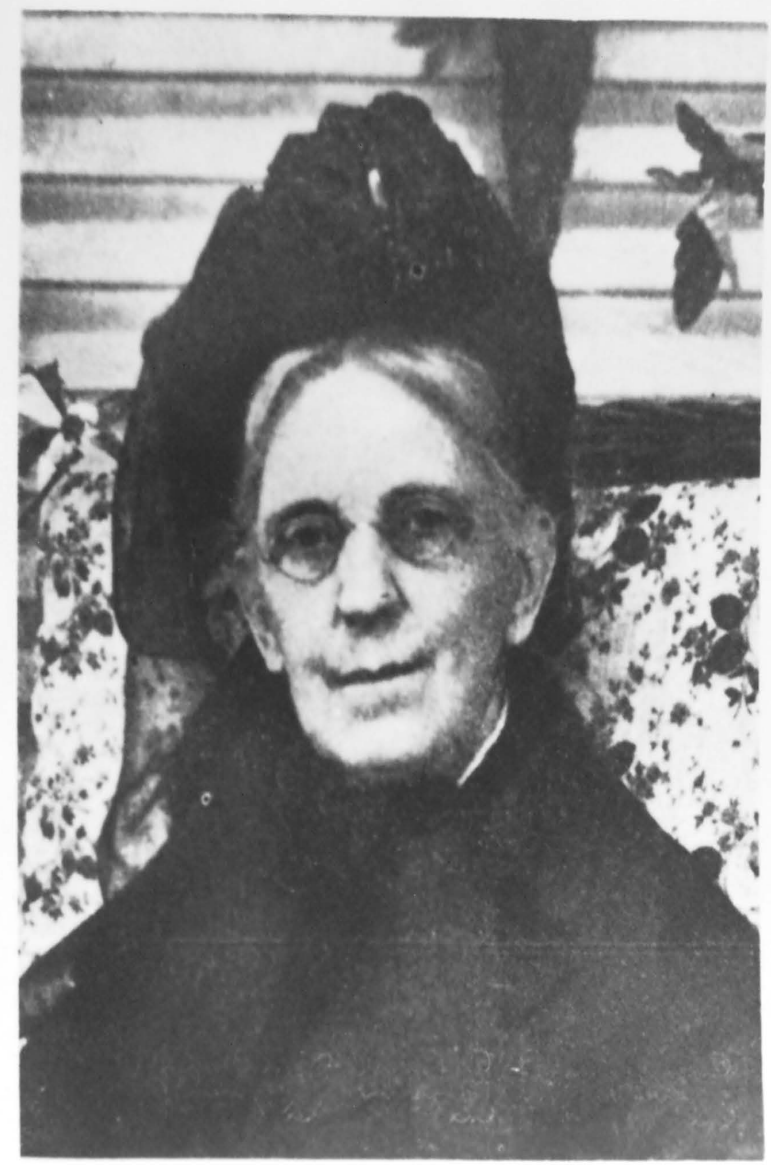

\section{FIGURE 4}

Miss Hatt1e Audubon 
or. watted to be helped in stores, she would knit or read, for she always carried in her purse sonothing with which to lreep occupted. She taught herself to read Bratlie so that in the night when she avakened and could not sleep, she could read the Braille without using a light,

Miss Audubon became Miss Belle's assistant principol in 1897 and rotired from active teaching the first part of the nineteenth century.

In Inter years when not ther Miss Audubon nor Miss Fannie Anderson was teaching, Wiss Hattie lived with Miss Fannie who had a boarding house for women. One day Miss Hattio boarded a stroetcas in a downtow area. A fow blocks farther on Miss Fannie boarded the same car and sat in the unoccupled seat next to Miss Hattie. Miss Hattie did not appear to notice Miss Fannie and when they had almost reached their destination, Miss Fannie inquired, Well, aren't you going to speak, Hattie?" Recognizing the volce she replied, "Fannfe, I thought there was something faniliar about you when you sat there." Miss Audubon also had great diffículty renembering peoples ${ }^{7}$ names, Upon meeting a person she would often have to say, "I know your face, but you will have to tell me your name."

Miss Audubon was quite tall1 and thin. She alvays wore a Ifttle white eap Indoors and a bonnet to cover this when she went out. She always wore white stockings because she 
thought the dye from the colored ones to be harmful. When Henry Gray, Miss Peers' great nephew, was in the "toddling" stage, he would crawl underneath the desk and tickle the white stockings. This active lady lived almost until her ninety-fifth birthday. When out of doors she would walk with a cane, a tall staff-like cane. In addition to the black bonnet, she wore a long cape instead of a coat. She was indeed a picture in black bonnet, long flowing cape, and tall cane as she walked along Fourth Street. At Halloween one small boy was heard to ask, "Is that a witch?"

First Newspaper. Among Miss Annie Anderson's possessions was a newspaper, The School-Bell, Louisville, Kentucky, June 1877, Vol. I., No.2. Although there was no statement that the paper was a Hone-School publication, the articles make this a conclusive fact. The first issue of The School Be11 appeared in January $1876 .^{34}$ Perhaps this was the first school paper printed in Kentucky. A column headed "School Chronicles" relates the following:

- . The twelfth of February was marked by one of the most delightful soirees we ever had. Our spacious schoolroom was quite filled with friends and relations, who came to see the improvement made during the half year. The Primary Class arranged in their brilliant costumes went through their dally drill in Calisthenics, which was hightly appreclated and enjoyed by the audience. We have had our usual rambles with our kind and

34

The School-Bel2, June 1877. 
Indulgent friend N. Butler. One day a walk to the river to behold the masses of ice quietly making their way down the Ohio River, (ed. There was an enormous ice gorge this winter) and another, a visit to Col. Durrett's greenhouse, where we passed a delightful hour examining the century-plants, orange trees, etc. and enjoying the sweet perfume of the many rare and lovely flowers, carrying our thoughts far off into the distant land where these plants grow so large and in such profuston. . . How many girls grumble because they have to go to school. The truth is they do not know how pleasant it is, or perhaps-.-may be they havn't (haven't) a Mr. Butler in their school to assist them in all their undertakings and to plan and carry out pleasant excursions for them. 35

217. Third Avemue. Since there were increasing demands for boarding accomodations the school was moved to 717 Third Avenue (Street) in 1880. The house, a large, square, white three story one set in a large yard, was a comfortable and conmodious home and school. The rooms were of great size. Jpon entering the house into an entrance hall that extended 2.11 the way to the back, the room at the right was the gymnasium. It was almost a great hall, for It occupled the same area that two of the normally large rooms would occupy. Here Miss Whittior conducted her famous classes of collsthenics. Horizontal bars were fastened to the wall and there were also Indian clubs and dumb-bells for exercising. The rooms on the opposite side of the hall were the parlor, where Miss Belle interviewed the students and their parents, and the dining room and kitchen. The bedrooms of Miss Belle, Miss Hattie, 


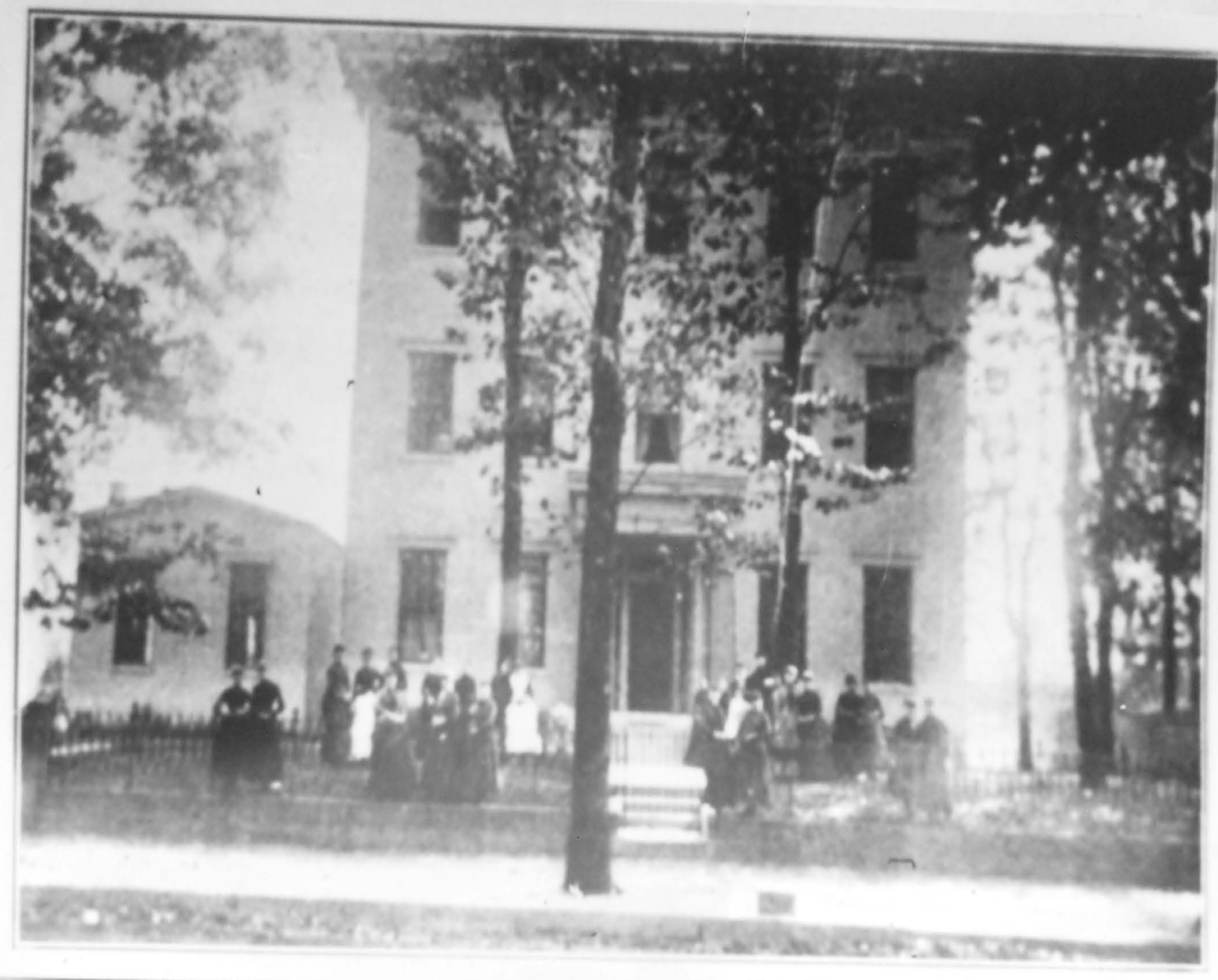

\section{FIGURE 5}

Horne-School. from 1880 To 1902

717 Third Street 
and from time to time other teachers and members of the family, were on the second floor. The third floor was occupled by the boarding students unt11 1891. Then the benevolent Miss Peers Invited her nephew, Benjamin Gray and his familiy to stay there. There were four of them, Mr. and Mrs. Cray, a daughter Henrietta, and a son Henry, Bxtending back from the house on the south side was an ell. It was of considderable size, for the two stories of this section contained the classrooms and Miss Ellen Whittier's room. The classrooms were large enough to accommodate ten to fifteen students. They were furnished with chairs and some, where subjects were taught that required writing, had blackboards and tables. The girls of the nineteenth century, just as those of the twentioth do, delighted in making the chalk screech on the blackboards.

The property at $717 \mathrm{Third}$ Avenue included large and spacious grounds surrounded by the customary wrought iron fence with a swinging gate at the entrance from the street. ${ }^{36}$ Miss Belle had a large, one story, white frame building (shown at the left in Figure 5) constructed. Along the side of the building closest to the house there was a hall where there were lockers for the girls' coats and hats. At either

\section{6} Willian Carnes Kendrick, "Old Reminiscences
Louisvizle," (Loulsville: mimeographed, n.d.), p. 14. 
end of the hall there was a door that entered into the main section of the building, one large room. Miss Belle called this the school-room. It had a platform at each end; the one fartherest from the street was occupied by Miss Belle and the school-room teacher. The senlors had the platform at the opposite end of the room. They each had a table and cha1r. In the center of the room there was a large, round, coal stove with large transparent panels around the sides near the top. The younger chlldren sat closer to the teacher, and 1t was an important event in the scholar's life when she could move beyond the stove to the section fartherest from the teacher's platform. The desiss were arranged in rows; the front of one desis served as the back for the desk in front of 1t and the desk 11d formed the writing surface. The school-room was used as an assembly room and study hall. When one was not in a class, she studied in this room, One teacher was omployed solely for the purpose of supervising this room. There was a small white ruler on the teacher's desk and when anyone left the room she took the ruler with her. If one went to the teacher's desk and found no ruler, she was to return to her own desk and walt for the absentee to return.

Mrs. Samuel Kirby says, "Around the walls were many windows and between them were the mottoes of the graduated 
classes emblazoned in the class colors." ${ }^{37}$

Changes in 1872. In 1379 there appears to have been some reorganization of classes, for oral French was Introduced in the Primary Department and a new department, the Intermediate Department, was added after the Primary Dew partment and preceding the Junior Class with the following course of study:

\section{8}

\section{INTERIMEDIATE DEPARTNENT}

$\begin{array}{ll}\text { Spelling, } & \text { Reading, } \\ \text { Writing, } & \text { Practical Arithmetic, } \\ \text { Mental Prithmetic, } & \text { History of United States, } \\ \text { Grammar (orally), } & \text { First Lessons in Composition. } \\ \text { Writing and reading were dropped from Senior Class }\end{array}$

studies, and a post graduate course in reading with an experienced guide was offered twice a week. The annual Bulletin explains its format thusly:

The Class . . .; w11l read some one of the great historians; also some of those standard works with which every person of liberal education should be acquainted; and an endeavor w117 be made to give some general knowledge of Ancient Greek and Roman Literature, The class vili be under the direction of Noble Butler, and in connection with it lessons in the Art of Blocution will be given by Miss E. Whittier. Nademolselle Fournier will also form a Class for

\section{7} Harriet Griswold Kirby, "The Chapel," Panda1sia
(Louisvilie: Kentucky Home School. for Girls, 1915), p. 7 .

38

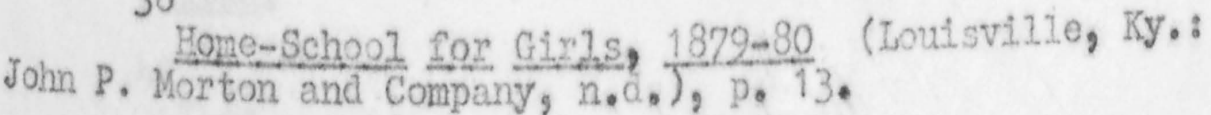


young 1odies, to meet once a week, for French conversa. tion and the study of standard French Literature. The members of this class rast be able to converse in French. 39

There was a slight change in tuttion at this time. rifty dollars a year was charged for the Primary Department; the Intermediate Department was sixty dollars, but the others remained the same. A two dollar charge for calisthenics is also noted.

The Baculty in 1872. There were few changes in the faculty from year to year except for adaitions, for by 1879 there were eleven full time mombers. Miss Bllen Whittier, the famous Anerican poet's cousin, taught Inglish and calisthenics, The calisthenics of that day were a great deal different from modern calisthenics. The movements were graceful and interpreted some thought, somewhat like modern ballet. Sometimes Miss Hattie Audubon played the plano to establish a rhythm for the motions. Blien Whittier was often called "Miss WhIt" by her students, and they all remember the calisthenic classes with amusement. Mademoiselle Fournier, one of Miss Belle's first

39 Ibj., p. 14 . 40

\section{Ibid.}

41 Ibid., p. 4 . 


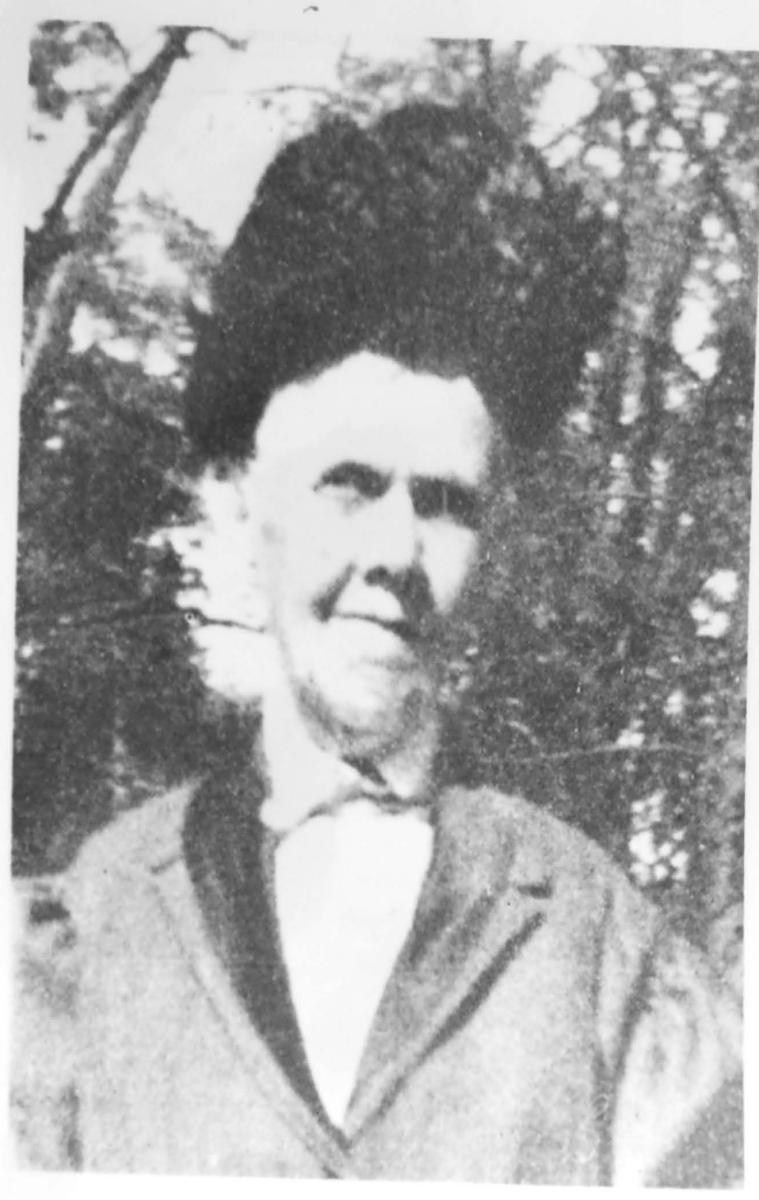

FIGURE 6

Miss Ellen Whittior 
French teachers, was a native of onleans. She taught for mowe than ten years in the late seventies and early eight42 Les and then returned to France. She made a deep and lasting impression on her associates and students, for before the United States entered. World War I, Mademoiselle's friends made bandages to send to her to be given to her brother, a French surgeon.

\section{A Charter for Kentucky Home Seminary. Miss Belle}

Peers' Home-School was Incorporated in 1882, and the charter which was granted reads:

An Act to incorporate the Kentucky Home Seminary of the city of Louisville.

Be it enacted by the General Assembly of the Conm momealth of Kentucky:

1. That R. A. Robinson, J. M. Robinson, W. George Anderson, John B. Temple, James W. Tate, Stephen B. Jones, Joseph B. Kinkead, Noble Butler, and Belle Peers, and their successors, are hereby created a. booy-corporate and politic under the name of the Kontucky Home Seminary, and by that name may sue and be sued, contract and be contracted with, in any court of law or equity; may have a common seal, and alter the same at pleasure; may have perpetual sucm cession; and may make all by-laws necessary for the transaction of the business, and for the government of said seminary, not inconsistent with the laws of this State or of the Unfted States.

2. That the said corporation may receive or acquire or hold, by gift grant, or othervise for oducational purpose, only as hereinafter expressed, property, real. and personal, in fee or for a term of years not exceeding fifty thousand dollars in value, within the city of Louisville and may from time to time sell or transier the same at pleasure, and invest the prom ceeds of sales on like terms and conditions. 
3. Since the object of this corporation is to esm tablish an Institution of learning of a high order for the education of giry.s and young women, the said corporation shall have power to confer such honorary degrees and diplomas as are usunl in the colleges of the Commonweal th.

4. The said corporation and their successors sham? have the power to elect a board of directors and such other officors as they may deem proper to perform such duties as may be imposed consistently with the purposes to be accomplished by this act.

5. This act shall take effect from its passage. Approved Apri1 $7,1882^{4}$

This seal is the only one known to have been used by the school.

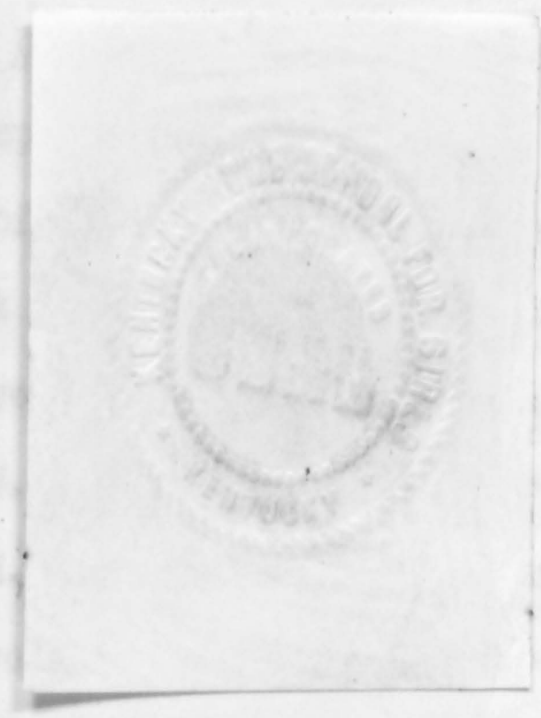

FIGUPE 7

Miss Peers always reforrod to the school as Homem

43

Acts of the Gonoral Assembly of the Commonveatth of Kentucky at the Regular Session of the General Assembiy, Which was besun and held in the city of rankfort on donday, the twenty-eighth day f November, Highteen hundred and eichty-one, (Frankiort, Kontucky: Kontucky Yooman Office, 1882), Vol. II, pp. $284-285$. 
School, even though the charter named it Kentucky Home Seminary. Aftor 1882, Bulletins st111 continued to call It Home-School for Girls until 1895-1896, then 1t became Kentucky Home-School for Girls. Although there are a fow instances when Home School was written as two words, durIng Miss Belle's leadership it was generally written as a hyphenated word, and school was written with a capital "S."

So far as is known there were no honorary degrees conferred although the charter granted the school this privllege.

Board of Directors. W. George Anderson of Thomas Anderson and Company; Joseph B. Kinkead, attomey at law; R. A. Robinson of R. A. Robinson and Company; Stophen E. Jones, president of Kentucky Wagon Manufacturing Company; J. B. Temple, president of Southern Mutual Life Insurance Company; Janes W. Tate, Kentucky State Treasurer; J. M. Robinson of J. K. Robinson and Company; and Henry W. Gray, representing Iiverpool, Iondon, and Globe Insurance Company, were the first Board of Directors after the school had been incorporated by the Legislature of Kentucky. They were all outstanding business or professional men of Loulsville. Nearly twenty years later Henry W. Gray and Stephen $\mathbb{E}$. Jones

44 John P. Nonton and Company, n. $\frac{\text { Home-School }}{\text { for , p. 4. }}$ (Louisv111e, Ky.: 
were still members, Charles $\mathbb{E}$. Johnson, Judge I, W. Bruce, Wililiam A, Robinson, probably R. A. Robinson's son, J. Edward Hardy, Henry Barret, and Charles $\mathbb{E}$. Pettet had replaced some of the first directors. The majority of these men served for a period of ten years or more. There is no record of how much the Board of Directors controlled the business of the school. Whether they approved the selecthon of teachers and the course of study or left this to Miss Peers, and how much they supervised the finances, is not known.

No Molephone! It is hard to pleture the schoolgirl's Iife in the late nineteenth century without a telephone. The Pirst telephone in Louisville was installed for Mr. J. B. Speed in 1879; however, in 1883 there were only 471400 subscribers out of Louisville's 155,000 population. Miss Belle never had one of these modern devices, but in great emergencies the girls would go to Pearson's Funeral Home

\section{5}

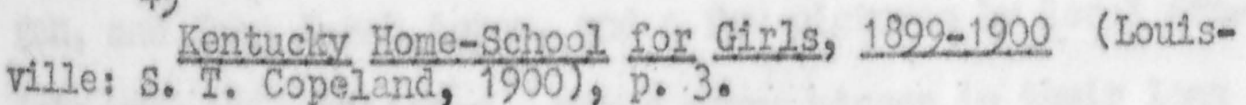
46 vilie, Kentucky: Iiberty National Bank and Trust Company, 1954), p. 159.

47

Ibid. p. 112. 
closo by on Chestaut Stroet. How thoy managed without a telophone In the school. to call theis mothors about last mimute after school plans wth theld frlonds, or how thoy procurod the book roport due today but loft on the desk or hall table is puzzling. Wo doubt such problous novor arose bocauso 14 fo at that porlod was moro 201 surely and mothode 1ca2. It vas nocessary that the dny's plans be ande vol? In edvance, and that the students undorstand thotg assigno nents before they loft school bocause thore wore fov who were fortunate onough to have a teleghone to call thels classuates to A1scuss the day's howowort:

The Southere Exposition an 1883. It is cortain that Mss Bollo oncouragod her students to see the Art Gallery at the Southorn Isposition, and porhaps Hise liattie ovon chaperonod a croup of boerding students who rode on tho Mrst Avenue mule dravm stroetcar. Palntings of the mastors fron the eallections of August Belnont, PLerpont Norgan, and John Jacob Astor, and a few pletures by Zocal artLsts vere on cochibltson. Theso yotung valsges in tholr long Aresses probably wore not able to see a.11 the exhibltion covering tho forty acro grounds, but it is hoped that thoy wero pomitted to stay late on ugh to see the 313unination of the exposition grounds by Edison's Incandescont oloctric 
lights, the most spectacular display up to this time.

Tomado of 1820. Loutisville has experienced a few cyclones and tornadoes, but the tornado of 1890 was the most destructive. Seventy-six lives were lost and two and a half million dollars damage was done to property. The school building withstood the fury of the tomado for it was somewhat out of the six block swath it cut at eight o'clock on a March evening in 1890, although pictures on the wall may have been twisted awry. Jessie and Isabel Clark, Home-School graduates of the class of 1886 who lived farther south on Third Avenue, held a party that evenIng without any delays or intermutions and the absence of only one guest. 50

The Eighties and Nineties. "In the eighties and nineties, they walked southward as well as northward, comIng to school In the morning--coming to Miss Belle's. FashIonable residences st1.1 lingered as far north as Walnut

48 Melvilie Briney, Fond Recollections, (Louisvilie, Kentucky: The Louisvilie Times, 1955), p. 109.

49 Relbel, op. ctt., p. 118. 50 Briney, op. cit., p. 123. 
Street! Lovely they were--these girls hastening to the old school-..." ${ }^{51}$ Chestnut and Walnut Streets between Second and Seventh Streets were the nucleus of louisville's prosperous citizens who sent their daughters to Miss Belle's, so most of the girls walked to school, although a few may have journied part of the way on mule drawn streetcars. It was quite a contrast to the "station wagon set" arriving at school today in driving groups. Nany are clad in socks and loafers, short madras skirts, "V1llager" blouses, and Shetland sweaters appliqued with horses. The girls of yesteryear wore long dresses reaching from halfway below the knees to the floor, depending upon the maturity of the girl, the older the girl the longer the dress. In warmer weather dresses were cotton w1th elbow length or long sleeves and collarbone high necks. Sashes and bows around the waist were the fashion. In winter the woolen dress had long sleeves and a high neck. The primary girls wore white pinafores over their dresses. The houses did not have central heating and 1t was necessary to wear long underwear in the winter. A considerable amount of time was spent folding the leg neatIy around the ankle so that it did not show in ugly buiges underneath the long black cotton or 1isle stockings (One

51 An Histor1ce, Sketch of Kentucky Home School for Girs, op. cit., p.5. 


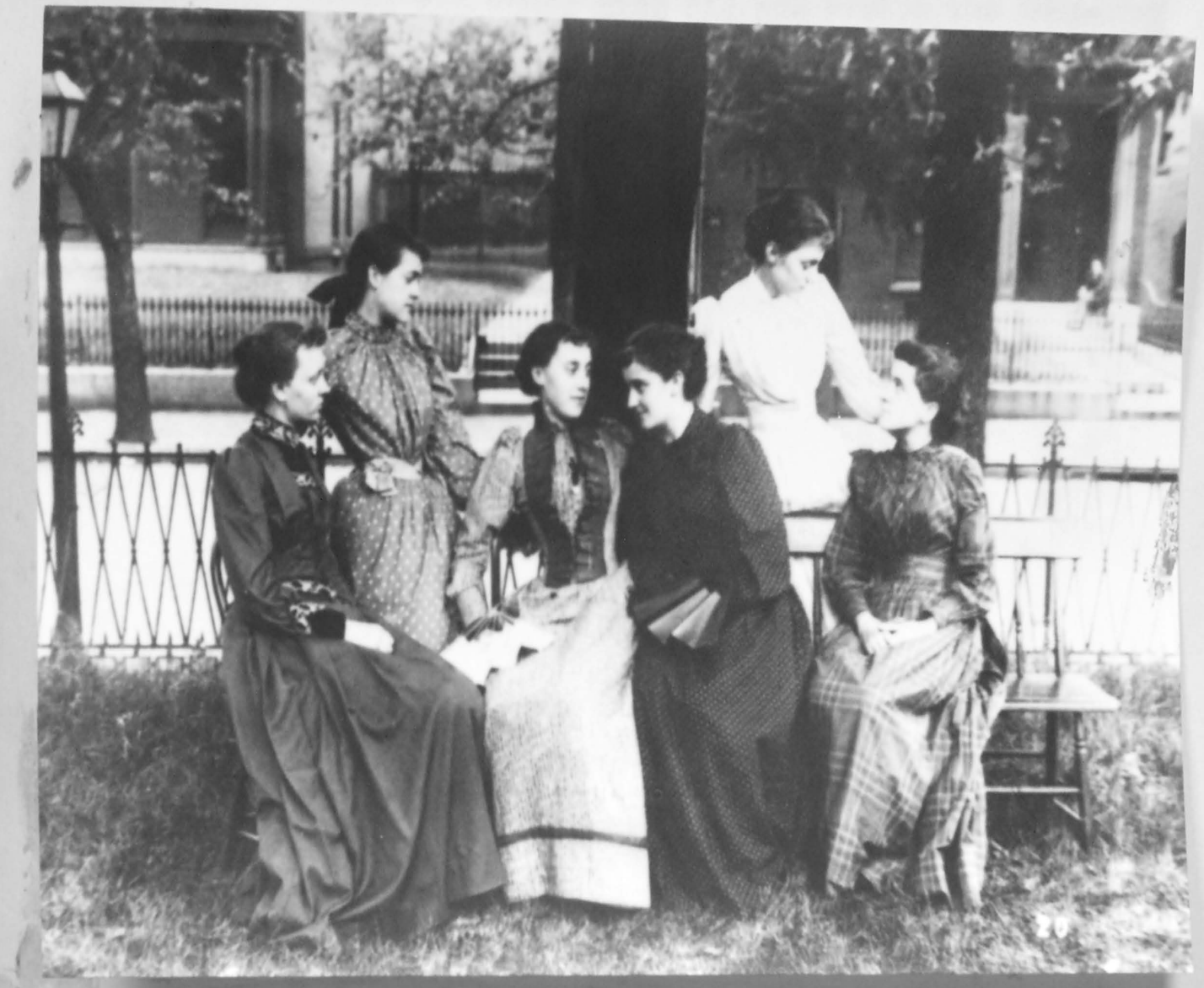

FIGURE 8

Home-Schooi Boarding Students in 1890 
thought herself quite a young lady when she was permitted to wear lisle stockings).

If per chance the young miss did not resist the temptation to valk in the water puddles on rainy days and she arrived at school with wet feet, her high button shoes and stockings were removed, and she usualiy was given a pair of Miss Hattie's white hose and some 111 fifting slippers to vear unt1l hers were dry.

Miss Jennie Benedict. Classes were over between one and one thirty; therefore, the students could be at home for lunch. Frequently, they brought sandwiches or other goodies to eat at recess in the midale of the morning. Many sampled Miss Jennie Benedict's delicacies from the pushcart which her helper John, a colored boy of all trades, pushed about to the private schools. Some of the elderly alumane will tell you to this day that nothing vas ever as delectable a.s Miss Jennie's chicken salad sandwiches eaten In the school yard at recess.

Miss Jennie Benedict was me of Louisville's fondly remembered "Institutions." When the family fortumes needed bolstering in 1893, she opened a catering business on South Fourth street. No one who Iived in this section will forget

52

Briney, op. c1t., p. 77 . 
MIss Jennie's birthday cakes with candied roses and loops of spun sugar ribbon and the lemon phosphate served at her soda fountain. Saturday lunch was quite an occasion when the young ladies of Home-School would neet at Miss Jemnie Benedict's to sample her delicious luncheon for twonty-five cents including dessert. A special treat was the Benedictine sandwich, Miss Jennie's orlginal concoction of cream cheese, onion and cucumber.

Shortly before she died in 1928 she wrote, "I thinis I have been the repository of more lovers' confidences than any other woman in Louisvilie." ${ }^{53}$ She fed their youthful appetites, Iistened to their confidences, and gave them from the store of her Victorian wisdom.

Cormencoment. For commencment the desks were removed from the schoolroom and chairs put in their places. The schoolgirls sat on the platform; the seniors in front and the rest of the school behind them. The letters, "Fervent in spirit," were cut out of blue and gold paper and strung on black thread across the top of the platform. Miss Hattie would play the comencement march and the school would enter one by one through the door from the outside hall that

53

Briney, op. cit., p. 78 .

54

IoId. 
lead to the platform. The smallest girl came first and, followed by the others in single file, she would move across the bottom tier of bleachers. When she reached the end, she stepped to the next tier and walked in the direco tion from which she had come. This was continued, tier by tier, until the top row was reached.

The program opened with prayer and the chorus sang. Then there were vocal and instrumental solos and duets by the music pupils interspersed with the Salutatory, compositions, and Valedictory. Medals were presented and Blshop T. U. Dudley would give the address and award the diplomas. In eighteen elghty-four, Margaret Hewett Leonard painted a word picture of commencement in rhyme, ninety-six lines of 1t. The first part of it is:

Commencement is here at last, friends. Now has come the eventful time When we all have to write compositions, And I have put mins in rhyme. 'Tis my pleasure to bid you "Welcome," And I do it with all my heart, For I'd far rather give you greeting Than tell you "One must part." How many times this schoolroom Has been filled as 1t is tonight! How often the good Bishop has risen To make the Cormencement speech, Which though it causes much laughter, Is always meant to teach. Though this room has seen many Commencements I hope it will see many more, I know they' 1.1 be well attended-Yes, crowded from stage to door. For they always are very pleasant, And the girls all dressed in white, 
With the stage trimmed in flowers and cedar Are surely a pretty sight. 55

The Course of Study after 1890. After another ten years, the Middle Class was specificelly divided Into two separate years of study. Latin was begun in the first year and algebra in the second. Both classes had daily readings in English classies. The Senior Class also had two definite years of study. Algebra and rhetoric were continued from the second year of the Middle Class, and the history of France, physiology and Shakespeare completed the year's work. Further study of Shakespeare was made in the second year of the Senior Class, as well as classes in geometry, physics, astronomy, and the history of England. The Graduating Class studied philosophy, Bnglish literature, Samson's Ant Criticism, Milton's Paradise Lost, and Dante's Inferno. ${ }^{56}$ Five years study of Latin was required by 1891 and "Those who do not wish to pursue Mathematics beyone Arithmetic may take an extended course in Latin with one Modem language in addition to the usual Bnglish studies, and receive a Diploma, A Diploma will be given to those who com-

55 "Salutatory and Valedictory Essays, 1876-1885," of. cit.

56

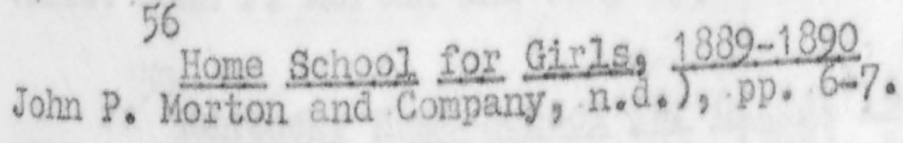

(Lovisville, $\mathrm{Ky} \cdot$ : 
plete the Course of Study."

Toward the end of the nineteenth century more young women were continuing theis education beyond the secondary level. Miss Belle encouraged the more capable graduates to pursue their studies in college. In 1896 the Bulletin makes this announcement: "A spectal Course of Study is arranged for those who want to prepare for College." And, in 1897 the Bulletin states this:

THE SUBJSCTS REQUIRED FOR ADMISSION TO COLLEG are Bnglish, Latin, Algebra, Geometry and History. Some colleges require but one language in addition to Latin, while others require two. The second language may be Greek or French; the thirâ, French or German.

English.---English, being the most important branch, is studied with great thoroughness. The principles of Composition and Rhetoric are taught in connection with the study of representative authors. Frequent themes are required.

Latin.--Latin is of so much importance, not only in its relations to other languages but as an aid in mental training, that at least two years' study of it is strongly recomended oven to those students not preparing for college. 59

It can be observed from the last Bulletin avallable auring Miss Belle Peers' principalship that she made fow

\section{7} John P. Morton, no d.

58 vilie: John P. Morton and Company, $\left.\frac{\text { Kentucky }}{1897}\right\} \frac{\text { Home-School }}{\text { D. } 7 \text {. }}$

59 ville: John P. Morton and Company, $\left.\frac{\text { Kentucky }}{1398}\right\}, \frac{1897-1}{\text { p. } 90}$ 
other changes in the course of study.

In 1890 the annual, announcements begin to list the text books to be used. Bach sueceeding year the size of the 11st Increases until. In 1900 most of the Upper School 61

texts are noted. At this time there were considerably

fever text books that had beon published, so there was not as wide a selection as there is today. Kentucky Homea School for Girls used generally the seme editions as other secondary schools of this pertod.

Muition and Errollnent in 1900. In the twenty-seven years extstence of Kentucky Eome-School for Girls there had been few changes in tuftion. The Primary Department fee was reduced to $\$ 50.00$ when the Intermediate Department was 62 added. The Juntor and Middle Classes were still the same, but the Senior Class fee had been increased to $\$ 100.00$ sometime between 1875 and 1880 . For the first time in 189798 the Bulletin does not mention an additional fee for

60

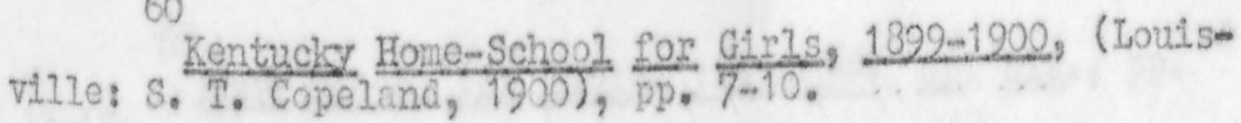
61 Ibid., p. 9.

62 Home-Schoo" Sor G1r]s, 1872-80, op. cit., p. 15. 63 Ibid. 
64

French and German. This additional fee for Latin had been 65 discontinued in 1882. Boarding and tuition together were $\$ 325$ in 1900. Although there had been a great financlal panie in 1893, this did not cause any reduction in the tuition. However, it reflocts in the number of students. In 1892 there were $114 ;^{67}$ in 1893,$75 ;^{68}$ in 1895,$94 ;$ and in $1896,76{ }^{70}$ Beyone this there is no accurate record of tuition or students until a number of years later.

Church Affiliation. Although not directly affilfated with the Episcopal Church, Home-School for Girls had many

\section{4}

7. 11. Kentucky Hone-School for Gin1s, 1897-1898, on. cfit.

65

Home-School for Girls, 1882-1883, on. citt., p. 8. 66 cit., p. 11 .

Kentucky Hone-School for Gir1s, 1899-1900, op.

\section{7} 14-16. Home School for Gile2s, 1892-1893, op. clt., pp. 13-15. Hone School oor Girls, 1823-1824, on. cit., pp.

69 $13-16$.

Home-School for Girls, 1895-1896, op. cit., pp. 70 cit., pp. Tentucky Home-School for Girls, 1896-1897, op. 
close ties. The first classes were held over the vestry room of Christ Church, and the following prayer was written for Miss Belle Peers' School by Doctor James Cralk, rector of Christ Church:

0 Thou King of Righteousness, grant that we may most strictly observe that sacred rule of doing unto others as we would they should do unto us; that so keeping innocency, and taking heed unto the thing that is right, we may have peace with Thee; through Jesus Christ our Lord. Amen 71

On Sunday the boarding students walked two by two to Christ Church to attend morning prayer. Because Miss Belle believed that Sunday was a day for religious activity and thought only, she read nothing but the Bible or religious articles. Games could be played if they were about Bible verses or characters. Everyone of the household; family, students, or boarders, had to obey this policy. The story is told that one sunday afternoon several of the boarding students were in the gyanasium. One of the girls was playIng some popular music on the piano when Miss Belle appeared at the door. The young lady nonchalantly continued the song but in the tempo of a hymn. Miss Belle's coment was, "What a lovely tune. I don't believe I've heard that hym before." It 1s presumed that Miss Belle was aware of the situation.

\section{1}

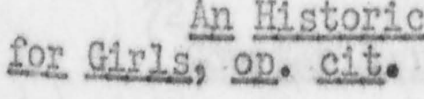


When the school moved to 717 Third Avenue (street), Bishop Dudley whose residence was across the street would come to the school each morning for chapel. He was chairman of the Board of Directors and a loyal friend and ad. Visor of Miss Belle. A coveted prize was the Bishop Dudley Necal for excellence in written and spoken composition for the three years preceding graduation.

The Right Reverend Thomas Underwood Dudley was Bpiscopal Bishop of Kentucky. He was a brilliant scholar, a powerful leader, and sald to be the greatest preacher of his time. He had a keen sense of humor and enjoyed life. He was particularly interested in education. Upon his graduation from the University of Virginia with a law diploma, he remained to teach Latin and Greek, After fighting in the War Between the States he studied for the ministry. In 1875 he became Bishop of the Diocese of Kentucky. Under his managenent the University of the South grew. He was a Vital member of the Board of Visitors of the Blind Institute. He also learned the deaf-mute language so he could preach to these handicapped people. 72

The school Rules published in the yearly Bulletin and taken from the twelfth chapter of Romans are:

Obey them that have the rule over you;

72

Courier Journal, January 30, 1916. 


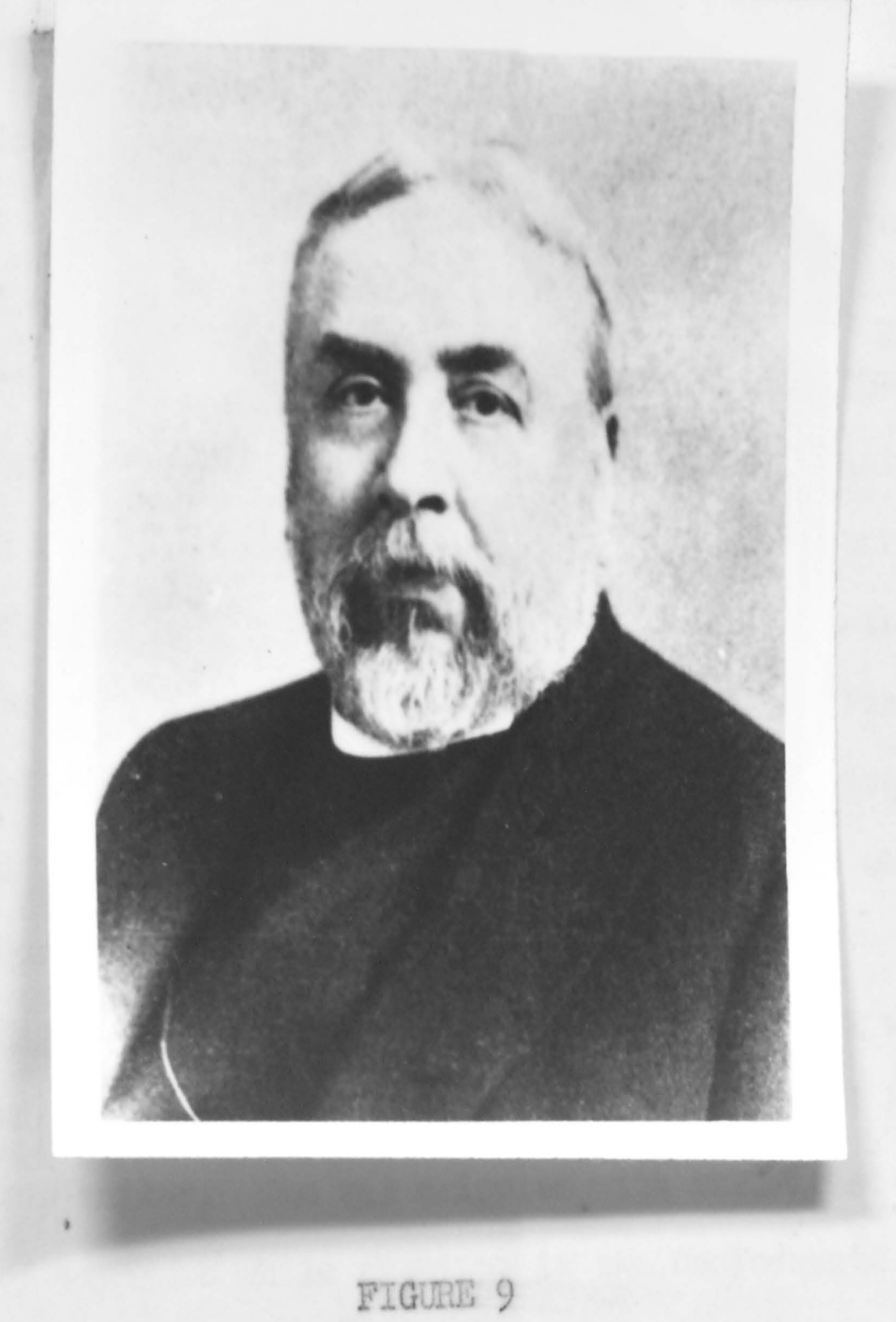

The Right Reverend Thomas Underwood Dudley 
Be kindly affectioned one to another:

In honor preferring one another;

Not slothful in business; 73

Fervent in spirit; serving the Lord.

Each morning the entire school met in the schoolroom for opening exercises called chapel. Miss Belle assigned a Bible verse to be learned each day and if the "scholar" had learned it, she replied "Ifive" when the roll was called. Otherwise she answered "present" or "late" as the case might be. Then Miss Belle would call on one girl to repeat the verse and a different girl to repeat each of the preceding verses of the particular chapter or Psalm which had been previously assigned, Grades were given and recorded on the monthiy report cards beside "word" which meant "Word of God,"

Ham. The school could not have functioned as well as It did without the services of Marah, the cook, and llam, the Negro janitor. Ham was crippled with rheumatism as a result of exposure while fighting in the Confederate Army In The War Between the States. He hobbled about in a large white or blue striped apron, bringing coal, tending fires and carrying away the ashes, On Narah's day off he would cook and make the most delicious beaten biscuit. Ham was

73 1876 school year (Loulsville: John P. Horton and Company, n.d.), p. 3 . 
never 1dle, for one job was rarely completed before Ham's services were needed elsewhere. Such was the case when he was called from his customary morning chores because the gong over the door in the schoolroom falled to sound at a quarter to nine. Ho arrived with his stepladder and prom ceeced to take wads of paper and cotton out of the gong. prominent Women. "The best result of a school education is a desire and capacity for self culture, and to the attainment of this result the best efforts of the school will be directed. ${ }^{74}$ Miss Peers was successful in projecting these 1deals to her students; to some in a greater degree than others. Many went oven farther to contribute and promote the culture and social welfare of the whole commu1ty. E1la Broadus was one of whom the school is justly proud. She became MrS. A. T. Robertson, the wife of the President of the Southorn Baptist Theological Seminary. But, in addition to fulfiling the duties of a mother and minister's wife, she wrote both poetry and prose, mach of which has been published. She wrote a translation of the Bible for children.

Hattie Bishop was a Home-School. student, although

\footnotetext{
74

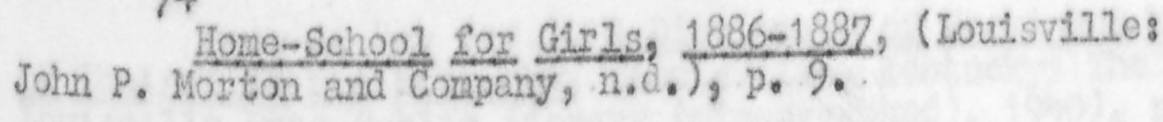


not a graduate, for aftor a few years here in school she studied music In the East. She was an accomplished musiclon. In later years she returned to Louisville and morried the capitalist, J. B. Speed. "An atrosphere of charm and culture surrounds this white-haired lady with the kindly satle and twinkling blue eyes . . . Her kindness and philanthropies, most of then designed to promote and broaden the cultural life of her native city are performed modestly and without ostentation." ${ }^{75}$ Mrs. Speed gave funds to the University of Louisville for an art museum as a memor1al to her husband. She had a music room built at her home on Ormsby Strect and brought many famous artists to Louisville such as; Marcel Dupre, Frances Alda, and Dr. Richard Burton. At her death the house and music room were given to the University of Louisvilie to be used for concerts and recitals. Outstanding artists who are not so well known publically are brought to the city through her endowment of a yearly concert series. She has maintrined Scholarships at the Universtty of Louisville for deserving young people. These are but a few of the many wonderful philanthroples Hattie Bishop Speed has left Louisville.

75

Bess A. Ray (ed.), A Dictionary of Prominent Women of Louisvil1e and Kentucky, TLoui svilie, Kentucky: The Louisville Free Public Library (nineographed), 1940), p.232. 
The humanitarian kinơness of Elizabeth Mladred Buchanon was spread halfvay around the earth. She was gradua. ted from Home-School in 1896 and returned in 1908 to teach Latin. A tangible evidence of her influence at the school is the Kentucky Home School. shield which she helped to design. At the end of the 1912-1913 school year Miss Buchanan left to become a missionary to China. She was principal of a school when the "Red" Chinese overran the the territory and the school was closed. Miss Buchanan then returned to IouisviJle and resumed her position as Latin teacher at Kentucky Home School.

Kentucky Home School's first kindergarten teacher, Miss Jane Akin, was a graduate of 1 ts class of 1891. She was a pioneer in this field of education and as a young woman began to study the psychology of little children. She was gradunted from the Louisville Kindergarten Training School, was one of a group of young women trained by Patty and Mary Hill, and later became an instructor at the Louisville Kindergarten Training School. While in the public schools she was one of the first teachers to hold mothers' meetings which later developed in the parent-teacher associations. She became known throughout the United States as an authority on kindergarten education e.s a result of the summer demonstration classes at Lancaster, ohio and Chatauqua, New York. Miss Akin was the kindergarten teacher 
at Kentucky Home School from 1910 to 1923.

As one looks around Memorial Auditorium or Columbla Auditoriun at the concerts and operas or visits the art exhibits, one sees many of the graduates of Home-School who are loyal supporters of these cultural aspects of the commity. There are those who have given many hours of volunteer service to the Red Cross, the hospitals, and other civic welfare agencies. Some have done splendid work for local and state political issues. A large percentage of the graduates who recelved college degrees entered the educational field. Still others have lest a deep Impression on the social life of their town. Then there are the great numbers who have been loyal wives and mothers.

\section{Kiss Peers, Principal. "Gentle dignity" were the} words used to describe Miss Belle. She never raised her volce, but when she spoke there was a firmness which denanded obecijence. She was very exacting but her pupils loved her. These paragraphs from the Bulletins explain her philosophy:

The rules of Home-school are few and simple. Their object is to secure order, comfort, and the general improvenent of the children; therefore, the principal requests that parents will kindly assist her in enforcing these rules, thus cultivating in their children a habit of obedience.76 
Parents and. Guardians are oarnestily invited to attend the daily exercises of the school. 77

Each boarder must be provided with a napkin-ring, table napkins, and towels, umbrella and overshoes, and all articles of clothing must be distinctly marked. It is particularly desired that the style of dress be marked by simplicity and neatness; expensive clothing and jevelyy are out of place in the schoolroom. There will be a recess of one weels at Christmas, when those who desire it may visit their friends: also two days' holiday at Easter, when the Principal begs that the children will be allowed to remain at the School, as their leaving at that time is a serious Interruption to school discipline and study.

A list of correspondents is required, written and signed by parents or guardian.

Boxes of eatables will not be recelved, as they prove a sertous injury to the chifdren. 78

When the city schools were given a holiday on George Washington's birthday, the students of Kentucky Home-School asked Niss Belle if they might also have a holiday. She replied that she was sure that if Goorge Washington wore asked for his opinion, he would say that it would be better for then to be in school.

These rules may seem rather rigid, but this was a period when chizden did not speak unless thoy were spolen to, and Miss Belle administered them with kindness and understanding.

The following tells of Miss Belle's move to her last

77

Home-School Sor Ginzs, 1884-1885, ap. ctit., p. 9. 78 Ibid. 
school bullding in 1902:

Barly in the present century, after long years of falthful service in the commity, her health and strength no longer equal to the caros and responstbilities of a large institution, Miss Peers leased a smaller building on Fourth Street, across from Central Park. 79

In 1904 when the lease on the property expired, Miss Belle, whose eyesight was rapldily falling, decided to accept the offer of the Misses Dodge and Davison to purchase the school. She had stated many times that she would keep the school unt1l her niece, Henrietta Gray, would be graduted. She did, however, stipulate in the bill of sale of the school that her niece should be given a full scholarship unt1I she was graduated two yoars hence.

The following is an account of Miss Belle's announcement to the school of her retirement:

It was near cormencement time, and we were a.1. busy vith examinations and plans for the next yoar. The classes had assembled in the schoolrom and prayer had just been sald, when Kiss Belle arose and sold that she vould like to make an announcement to the school. Ve were very much exclted and wondered what it could possibly be. Miss Belle had aged very moch during the year, and her placid thoughtful face seemed a 11ttile sadder. A lady, a stranger to us all, had jolned her and was seated hear her as she stood to speak. Miss Belle told us that she had been thinkting it over for a long time, and had decided that it would be better for a younger woman to take her place. She sald that she felt very sad at parting with 0.11 the girls, some of whose mothers she had taught before them but that her life's work was over. Some of us had been in the school since we were mere babies Ing at the age of five. We were of course greatly distressed.

We were then introducod to Miss Dodge as one of the 
new principala: . •

Thus 2t was thet an Importent pist of Kontuclay Home School's history vas concluded.

8o Pandaisia (Louisvilie: Kentucky Home School for Girls, $1915), 2.10$. 


\section{CIAPIER IV}

THE SCHOOL FROM 1904 TO 1908

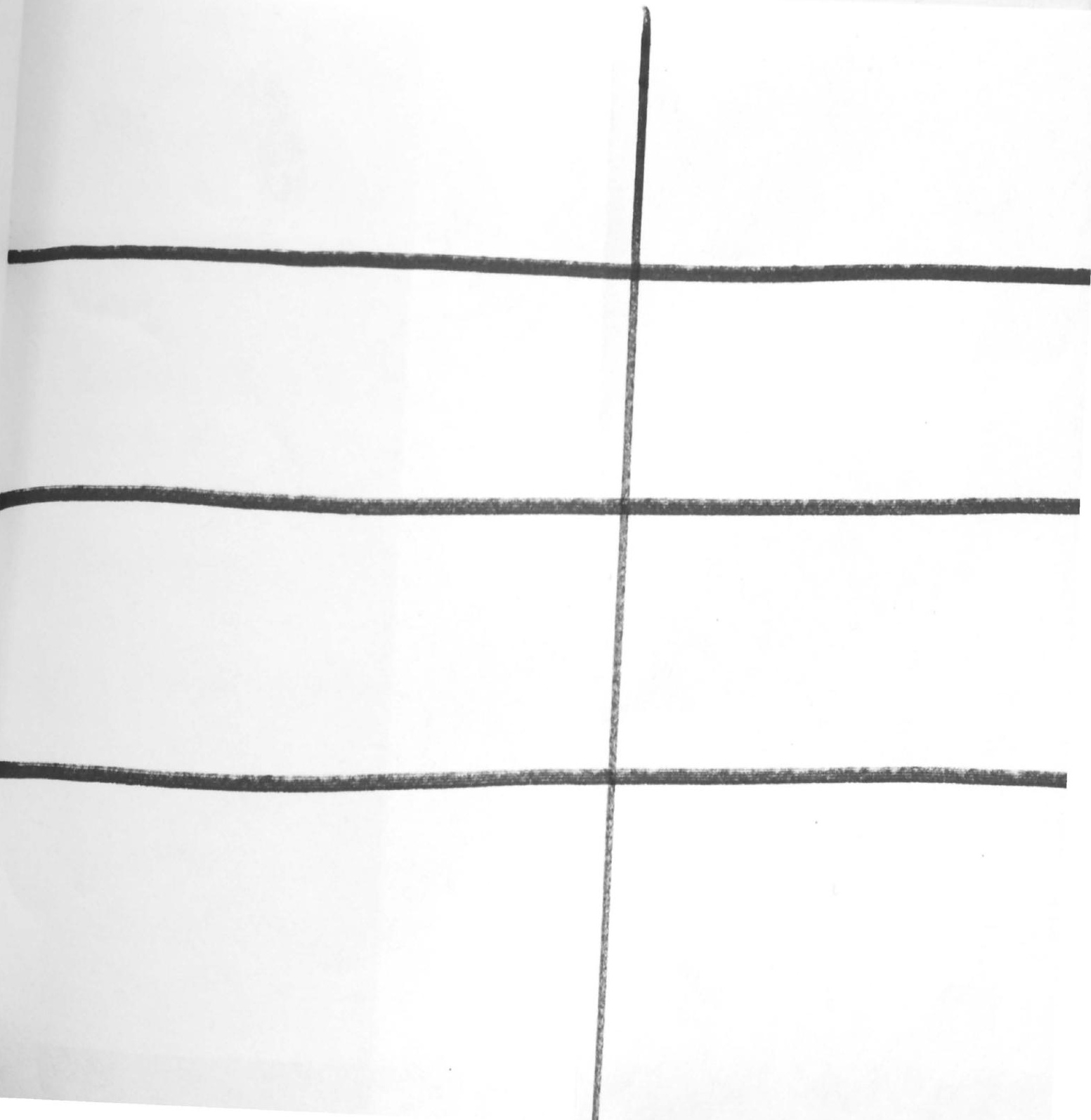


Introduction. In this short pertod of the school's history from 1904 to 1908, there were more changes than at any other period. The school changed ownership twice and the name was changed. Not all of these were improvements, and this chapter will note its course forvard as well as backward.

Beginning the Mventieth Century: The first part of the twentieth century was a transition period betveen the "gay-nineties" and the "roaring-twenties." The old was changing rapidly in some instances and slovily in others. Loutsvilie had expanded and the mudholes and board walks south of Broadway that were prevalent beiore the turn of the century had been paved and the open dralnage ditches covered. The fashionable residential area was moving from Walnut and Chestmut Streets to Second, Third, and Fourth Streets south of Brondway. The last muleddrawn streetcars disappeared from the streets in favor of the new electric models.

Women were still wearing long, dirt-catehing skirts, high neciks, nipped-In waists and modified bustles, Readymade dresses had not come into existence and the dressmaker was stinl an important enterprise. Such talented women as 
Nadame Glover were making lovely and elaborate creations of velvet and brocade.

Although this period was one mainly of progress in communication, the automobile and alrplane, and urban 1.1Ving, Loulsville can exhibit some educational and cultural advancement. The first moving picture house was opened in 1904. The moving picture has become a valuable teaching aid even though present day Hollywood aspects seem to echo degeneration rather than progress.

In 1905 the Louisville Free Public Library began in temporary quarters at the Kaufman-straus butlding. Three years later the library building was completed, having received a. grant of $\$ 250,000$ from Andrew Carnegie. Three hundred thousand books were checked out the first day.

Blien Scott Davison and Louise Preston Dodge. Ellen Davison had once been a pupil of Miss Peers. Both she and Louise Dodge were graduates of Wellesley College. Miss Dodge also recelved a degree of doctor of philosophy from Yale University, and she, as well as Miss Davison, had been

1

R. C. Riobol (eả.), Louisville Panorana (Louisvilie, Kentucky: Iiberty National Bank and Trust Company, 1954), p. 140 .

2

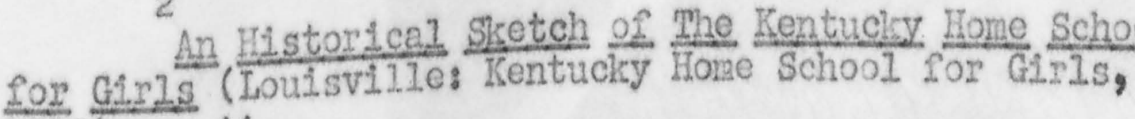

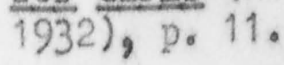




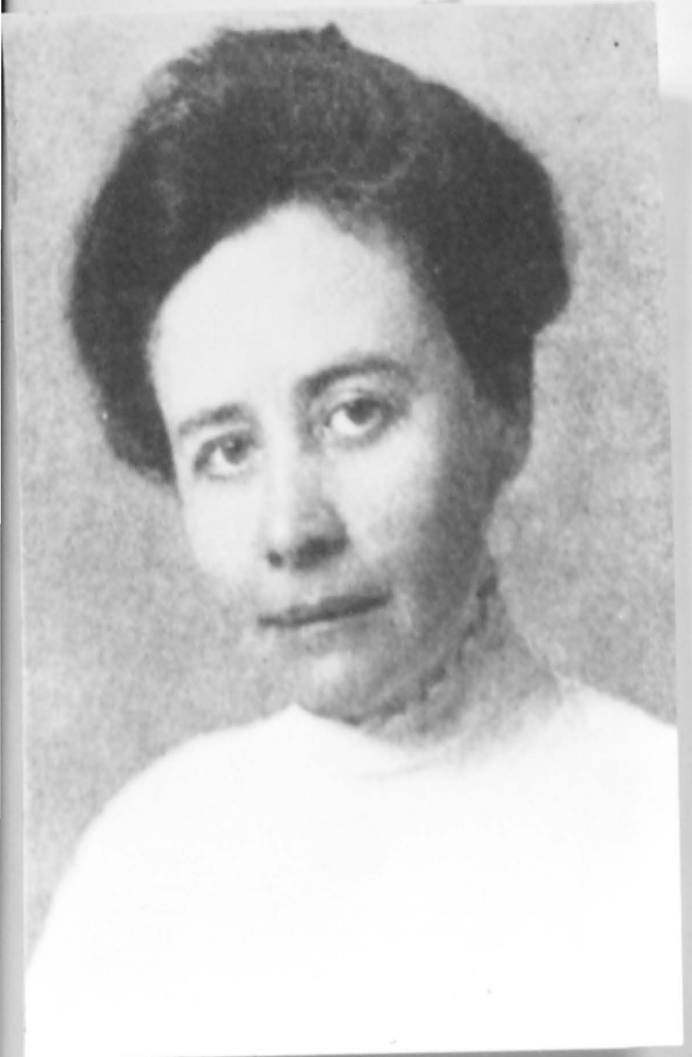

\section{FIGURE 10}

Miss Bllen Scott Davison

\section{FIGURE 11}

Miss Louise Preston Dodge

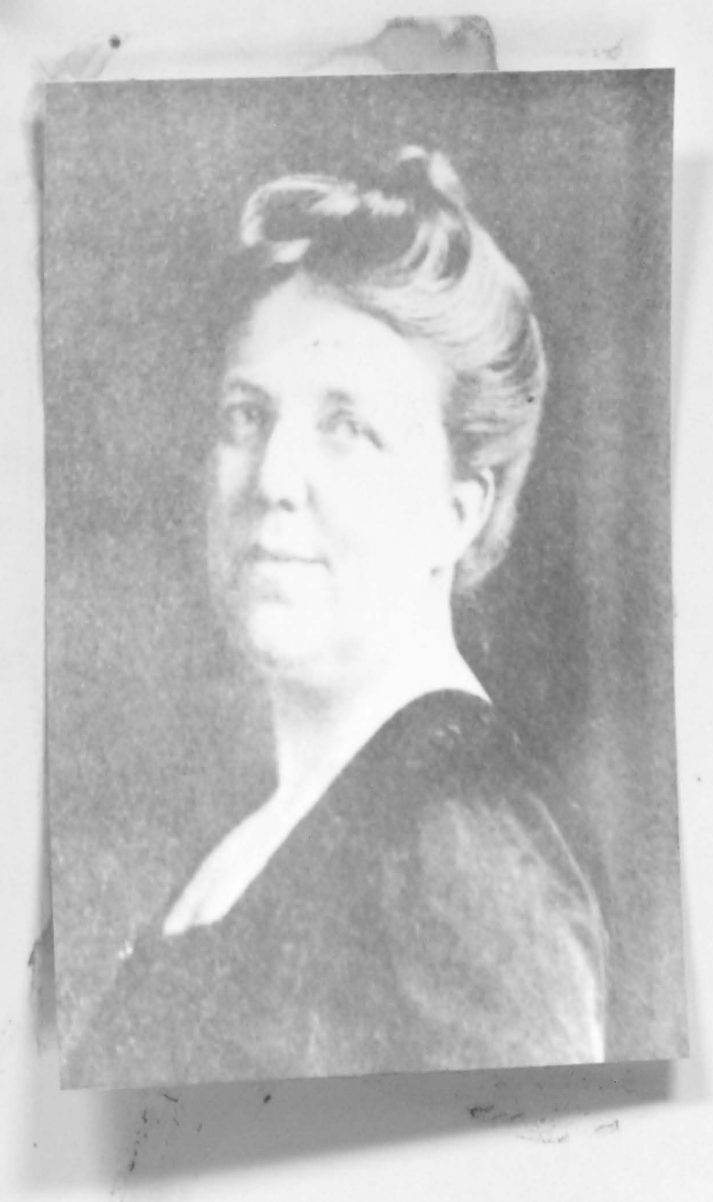


members of the faculty of Bryn Mawr College and other colleges. After the Davison-Dodge School vas sold to Miss Calhoun, "Yiss Davison taught history at famous old Bradford Acadeny and from there was called to be the first principal of Shady Hill School In Cambridge, Massachusetts." ${ }^{3}$ In the meantime she vas requested to become a mernber of the comission appointed by the President for the purpose of gathering data bearing upon the foreign relations of the United States for use at the Peach Conference.

Davison-Dodge school for Girls. After Miss Davison and Miss Dodge bought the school from Miss Peers they changed Its name to the Davison-Dodge School for Girls. They purchased a large home at 1220 Fourth Street to house the school. It was a good location at this time for many of the pupils lived in this section of town and could walk to school which was the customary means of travel to and from school in this day.

The following paragraphs from the school Bulletin explain the school's aims:

The school provides a thorough and well-rounded course for girls whose school years are to end with

\section{3} for Girls, $\frac{\text { Historic }}{\text { op. cit. }}$

4 Herald-Post, Sept. 19, 1921. 


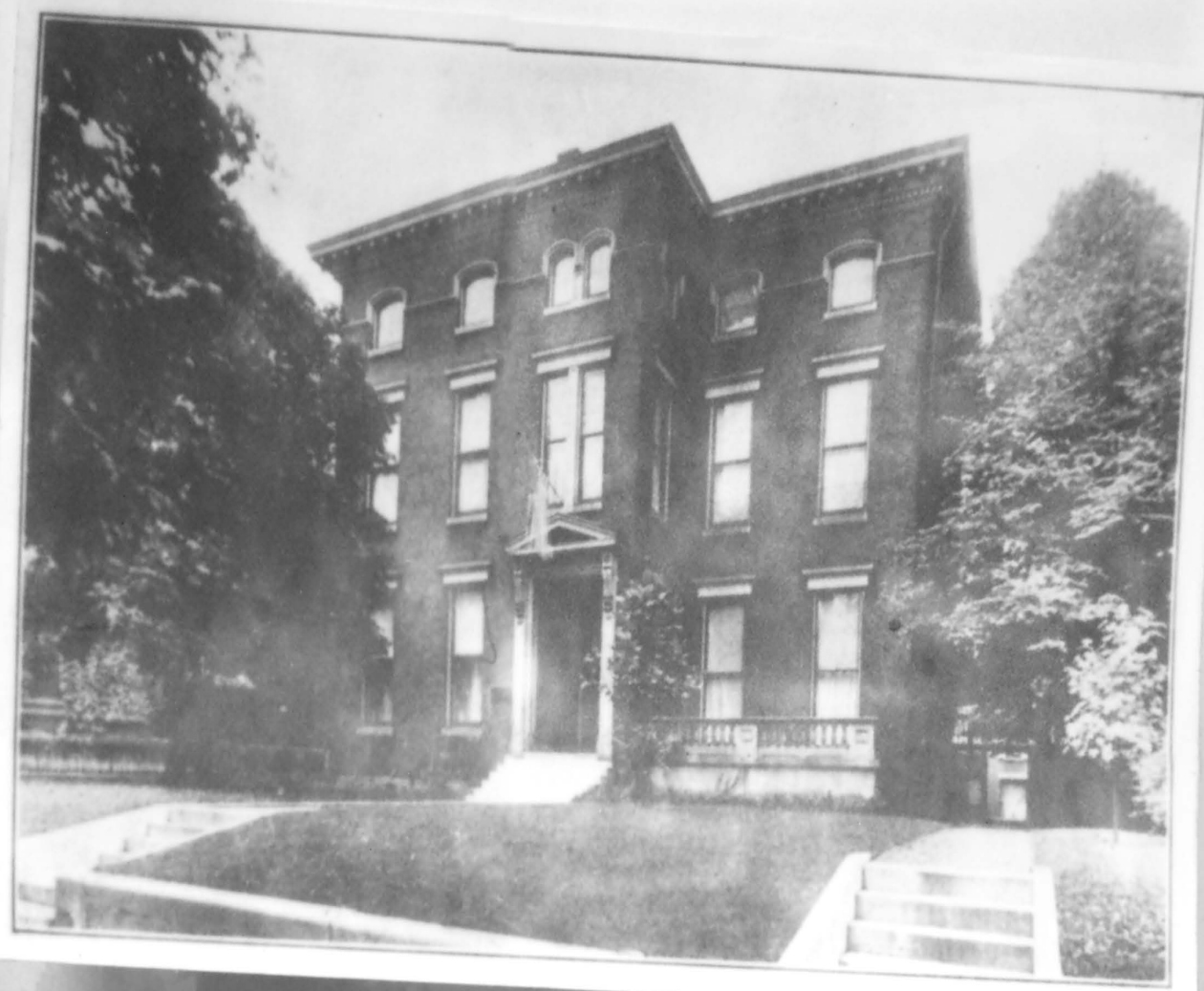

?

FIGURE 12

1220 Fourth Street 
their graduation from it. It also prepares for college and furnishes facilities for spectal and for advanced work. Bach pup11 w111 be considered. individually, and her studies arranged in accordance with her particular needs.

It is intended that the instruction in the school shall be of the best, and thorough and earnest work will be expected of every pup11. 5

Course of Study. This Schedule of School-Work by Classes was published in the Bulletin:

INTERMEDIATE DEPARTMENT

Lower Class

Arithmetic

Writing

Manual Training

Singing
Engl1sh Grammar Reading and Spelling Geography (includes Nature Study)

Upper Class

Arithmetic

Greek History

Singing

Reading and Spelling
Physical Geography

Writing

English Granmar

French

UPPER SCHOOL
First Year
Algebra
Roman History
English
French
Latin
Second Year Algebra English History English French Iatin

Work In Science arranged lf desired. Third Year

Prescribed

Geometry

American History

Prescribed

Mediaeval History

History of Art

\section{5} $1906-1907)$, p. 3.

Davison-Dodge School for Girls (Louisvilie: n.p., 
English

French

Blectives

Iatin or Science

(Provided two years of satisfactory work in Latin have been done)
English

Electives

Three may be chosen

Greek

Latin

French

German

Italian

Mathematics

Science

\section{Fifth Year \\ Prescribed \\ Modern History \\ History of Art \\ English}

\section{Electives}

Three may be chosen

Physlography (Required of all puplls who do not pass a satisfactory examination in Geography)

Iatin

French

Italian

\section{Greek}

German

Science

\section{Mathematics}

Drill in spelling is given in comection with all class work. 6

The Primary Department which probably covered five years work aimed "to establish a thorough and sound edvcational basis and to train the pupils in right habits of thought and action."

These further comments related to the Primary De-

6

Ibid., pp. 13-15

7

Ibid., pp. 10-11. 
partsent were made:

Careful attention is given to the reading both of prose and poetry from the time the pupil begins to read. In this connection a system of phonics is used to assist the children in forming the habit of self reliance in the mastering of woras. . The children are trained to give oral and written reproductionsof fables, stories, and short pooms. The more formal work in English Gramar begins in the fourth yoar . . •

Da1ly exercises are given in spelling and penmanship and careful attention along these lines is paid to all written work.

The Nature-Study 1s based upon the plant and animal life characteristic of the season of the year.8

The Upper School consisted of five years work beginning with a program comparable to the present day advanced eighth grade classes 1 in the public secondary schools. The Primary and Intermediate Departments constituted the Lower School and included seven years study.

The Misses Davison and Dodge Introduced Greek and Italian in the Upper School course of study. This is the ilrst printed record of the girls having had any choice in the subjects they would study.

Miss Peers had made arrangements for those girls who wished to continue thoir education to have the necessary preparation to enter college. The Davison-Dodge School continued to meet this need. The 1dea that a young woman vas entitled to a college education just as much as her 
brother was becoming more widespread, although the 1dea of a career for women other than teaching was not generaliy accepted by soclety nor was the fact that a college education might be valuable for the mother and homemaker.

Colisthenics continued to be a part of the school program and thus can be seen the trend toward more vigorous exercise for girls. In the nineteenth century this was not considered proper for young ladies. The yearly Bulletin. gives the following explanation about calisthenics:

Thorough instruction is provided for a.ll pupils, and forms part of the regular work of the school. The swedish system of Gymastics is folioved, conbined with certain features of that of Delsarte. Classes will be formed in Fencing and in Corrective Dancing when desired, and the general needs of the young girl, as well as those of the special pupil arc consulted. For the regular group-work no charge is made, and this can onily be omitted by conference with the Principals.9

Tuition. The tuftion for the Primary Department was $\$ 100.00$ per year, twice Home-School's foe. The IntermedLate Department was $\$ 125.00$, more than double what It had been. For the Upper School and pupils over fourteen years of age the tuition was $\$ 150,00$. For French in the fourth and fifth years of the Upper School, for German (except in the Primary Department and the college-preparatory course), 
for Italian, and for Greek, a charge of $\$ 25.00$ a year was 10 made,

There was a boarding department for which a charge 11 of $\$ 450.00$ was made in addition to tuition. If these school fees indicate a true picture of the general financial condition of the time, there had been a one hundred percent irization within a ten year pertod.

The Stafe. In addition to the two principals, there were seven regular teachers, a lecturer in geography, and a supervisor of the home life of the school. Only one of these teachers had been with Miss Belle, She was Mademoiselle Teburier, a young Frenchwoman, who began teaching there about 1895 .

Class of 1905. Most of the girls who vould have been graduated in 1905 were not more than sixteen years old and their parents asked that another year be added to their course, therefore, there were no graduates in this year.

Davison-Dodge School Sold. There is very little Information avallable about the Davison-Dodge 'School. Only

10

Ibid., p. 16

11

Ibid.

12

Home-School for Girls, 1895-1896, op. cit., p. 5. 
one Bulletin can be found, Perhaps these ladies did not revain here long enough to have made a lasting impression. At the close of the 1907-1908 school year the DavisonDodge School was sold,

Kentucky Hor:e School Again. Miss Lelia Calhoun bought the school from Miss Davison and Miss Dodge and retunned to the use of f.ts old name, Kentucky Home School Por Girls. She continued to use the same house, 1220 Pourth Street, for the school.

Miss Celhoun's curriculum. The new principal rew organized the curriculum into three courses of study. The yearly Bulletin analyzes them in the following manner:

I. A modern academic course of five years, with diplona.

II. A college preparatory course of four years with certificate.

III. A special course for those wishing to do advanced vork,

The Academic Department

This department w111 furnish a thorough and wellrounded course for girls not going to college.

\section{3}

An Historical History of the Kentucky Home School Lipls, ap. cit., p. 11.

14

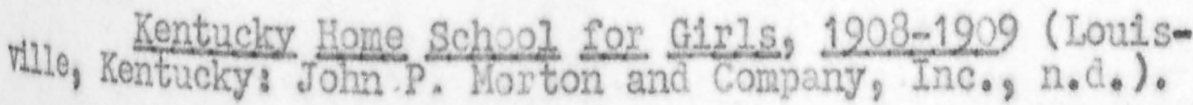




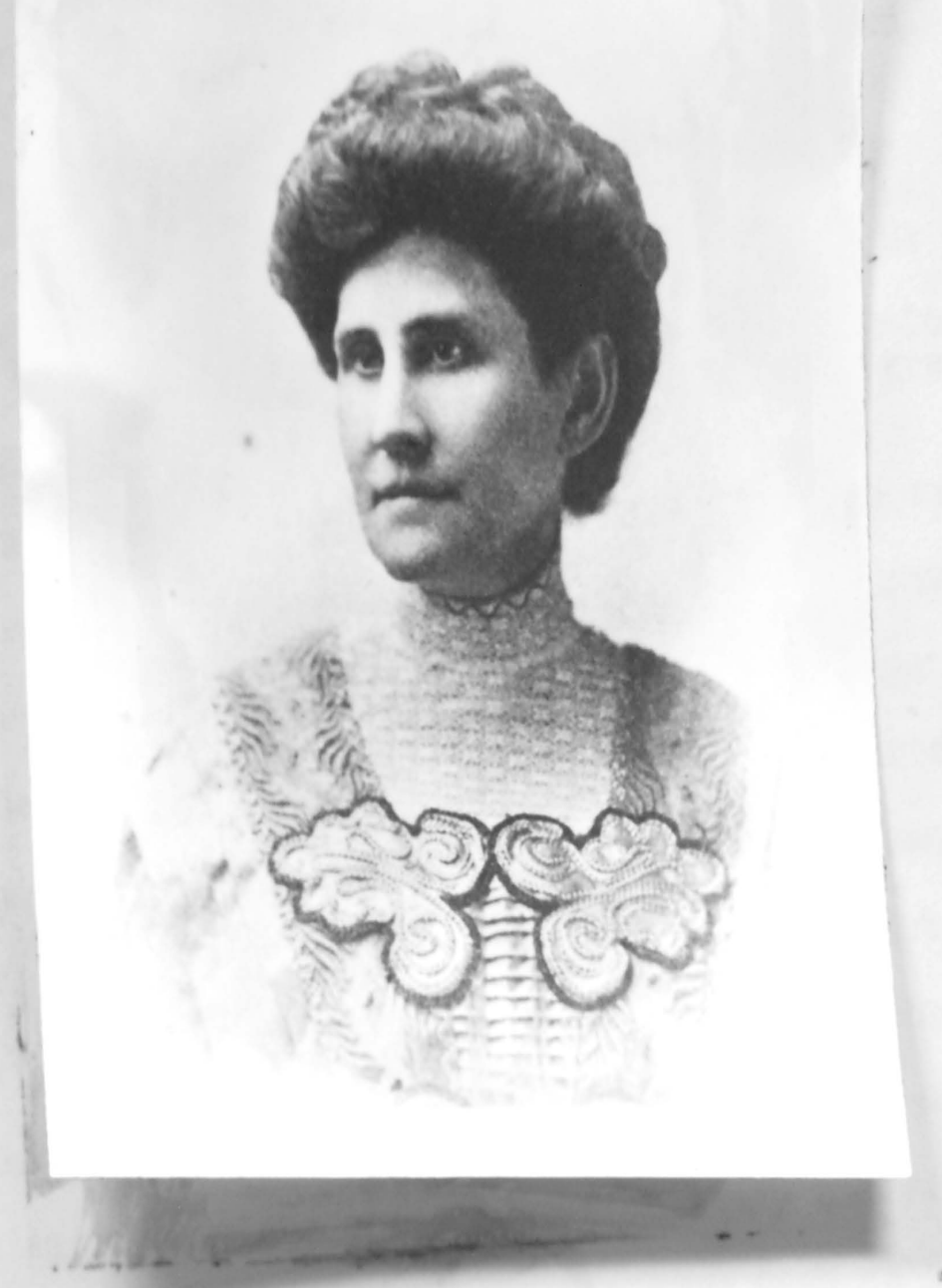

FIGURS 13

Mrs. Peter Leidenger

(Miss Lelia Calhoun) 
The College Preparatory Department

The college preparatory course is modeled on the uniform requirements of the College Entrance Examination Board, and embraces a.11 the subjects accepted for admission to any of the leading colleges for women . .

Those having completed the college preparatory course w111 be admitted to the senior class of the acadomic course, wh1ch will furnish instruction in collegiate subjects.

The freshman and sophomore years of the academic course will be the same as those of the college preparatory. 15

Figure 14 and Figure 15 are an outline of the academic and college preparatory courses. There is a somewhat different concept in the rolationship of the course of study designed for terminal education to the course of study designed for college preparation than the concept in use today. The school offered to those who would not have the opportunity of further education some of the courses offered in college. In the contemporary school those who do not plan to continue their education study the subjects of a general course or a vocational course such as business or shop. Languages are not required nor are the theoretic mathematic courses required of students not planning to attend college.

Under Miss Annie Vaters, Head of the Primary and Intermediate Departments, there was a reorganization of the 
ACADEMIC COURSE--(Outline.)

\begin{tabular}{|c|c|c|c|c|}
\hline Sub-Freshman & Freshman & Sophomore & Junior & Senior \\
\hline English & English & English & English & English \\
\hline Algebra & Algebra & Plane Geometry & $\begin{array}{l}\text { Solid Geometry } \\
\text { (elective) }\end{array}$ & $\begin{array}{c}\text { Trigonometry } \\
\text { (elective) }\end{array}$ \\
\hline Latin & Latin & Latin & $\begin{array}{c}\text { Latin } \\
\text { (elective) }\end{array}$ & $\begin{array}{c}\text { Latin } \\
\text { (elective) }\end{array}$ \\
\hline , & $\begin{array}{c}\text { Grteck } \\
\text { (elective) }\end{array}$ & $\begin{array}{c}\text { Greek } \\
\text { (elective) }\end{array}$ & $\begin{array}{c}\text { Greek } \\
\text { (elective) }\end{array}$ & $\begin{array}{l}\text { Psychology, Soci- } \\
\text { ology and Ethics }\end{array}$ \\
\hline $\begin{array}{c}\text { German } \\
\text { or }\end{array}$ & $\begin{array}{c}\text { German } \\
\text { of }\end{array}$ & $\begin{array}{c}\text { German } \\
\text { or } \\
\end{array}$ & $\begin{array}{l}\text { German } \\
\text { (elective) }\end{array}$ & $\begin{array}{c}\text { French and German } \\
\text { (electives) }\end{array}$ \\
\hline French & French & French & $\begin{array}{c}\text { French } \\
\text { (elective) }\end{array}$ & History of Art \\
\hline $\begin{array}{l}\text { Physical } \\
\text { Geography }\end{array}$ & & Botany & $\begin{array}{l}\text { Chemistry } \\
\text { or Physics }\end{array}$ & $\begin{array}{l}\text { Astronomy } \\
\text { or Geology }\end{array}$ \\
\hline English History & Physiology & $\begin{array}{c}\text { Mediaeval and } \\
\text { Modern History }\end{array}$ & $\begin{array}{l}\text { Advanced American } \\
\text { History and Civics }\end{array}$ & $\begin{array}{l}\text { Entengive Course in } \\
\text { Moden Hintory or Critical } \\
\text { Stody of Fieach History }\end{array}$ \\
\hline
\end{tabular}

\section{FIGURE $14 \%$}

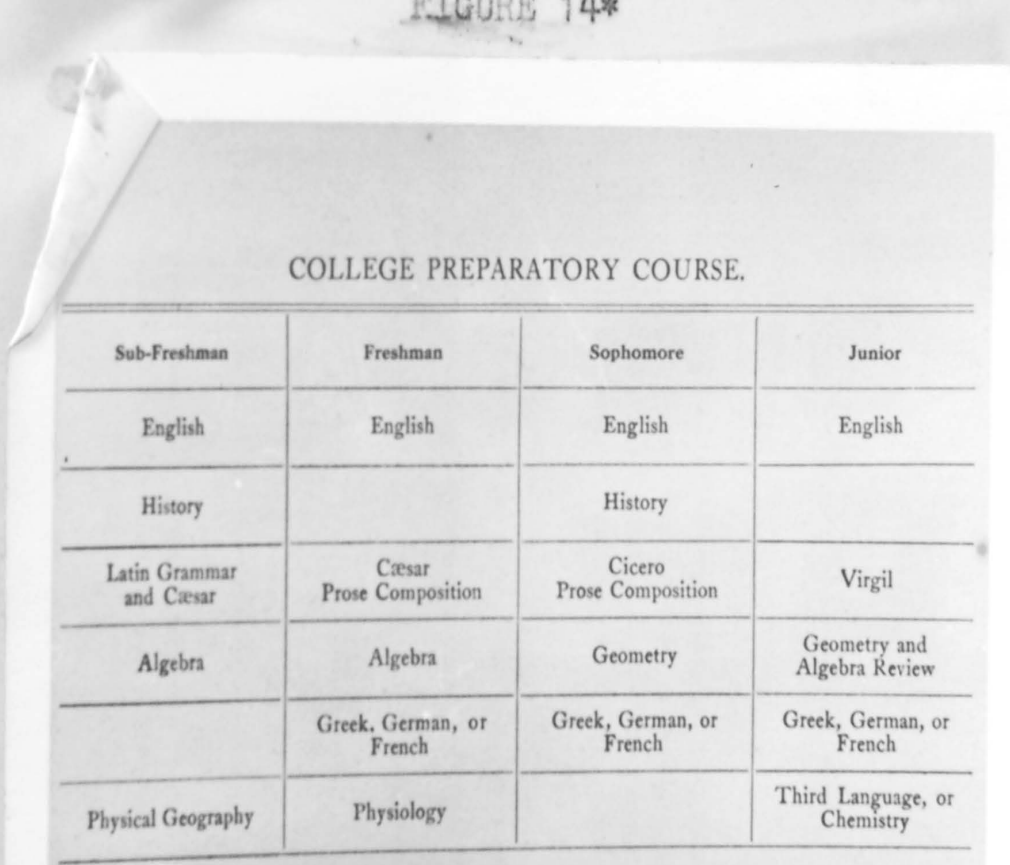

\section{FIGURE 15*}

*Kentucky Home School for Girls, 1908-1909 (Louisville, Kentucky: John P. Morton and Company, Inc., n.d.) 
groupings. The Primary Department incluced three years work In reading, spelining, language, numbers writing, nature study, manual training and French or German. French, taught orally, had always been offered in the primary grades, but now German vas offered as an alternative. German at this age level appeared in the Course of Study for one year only. The Intermediate Department embodifed four years of study. In addition to classes in reading, spelling, language, arithmetic, writing, nature study, and French or German; geography, history and composition were prescribed. Sight singing, handicrafts, and physical culture were taught each of the four years.

The school hours continued to be $8: 45$ a.m. to $1: 30$ p.m, During these hours there was a recess when the chilaren ate and had time for recreation. "A light luncheon was served at recess at a moderate charge."

Ruition. In 1908 the tuition for the Primary Department was $\$ 100.00$ and for the Intermediate $\$ 125.00$. The academic course was $\$ 150.00$; the college preparatory, $\$ 175.00$; Greek, $\$ 25.00$; Spanish, $\$ 36.00$; chemistry laboratory fee, $\$ 10.00$; and physics laboratory fee, $\$ 5.00$. For French and

16

\section{Ibid.}

17 
German in the fourth and fifth years of the academic course a charge of $\$ 25.00$ was made, The tuition included instruction in choral singing, and physical culture.

A limited number of boarders was admitted. The board and tultion was $\$ 500.00$. "This includes instruction in regular subjects, French, German, Chorus Singing, Physical culture, pew rent, plain laundry (16 pieces)." Madame Prevost, the French teacher, lived at the school and it was custonary to carry on French conversations in the boarding school. The Shield. Under Miss Calhoun's guidance Kentucky Home School pioneered many projects. With the help of Miss Mildred Buchanan, the Latin and history teacher whom we have already mentioned, a motto was adopted and a shield designed. It has been a standard for the school over since and is always used on cover designs and invitations.

The Kentucky Home School shield has two main parts; the crossed quill and torch which signify Knowledge and Strength or Courage, and the Greek letters $A 0 \pi$. The $A 0 T$ represents the motto of the school, OUDBV AVBU HOVOU; translated it means "Nothing Without To1." This quotation was taken from Chapter I, Book II of Xenophon's Memorabila.

\section{IbId.}

19

Annie Anderson, "Notes." 


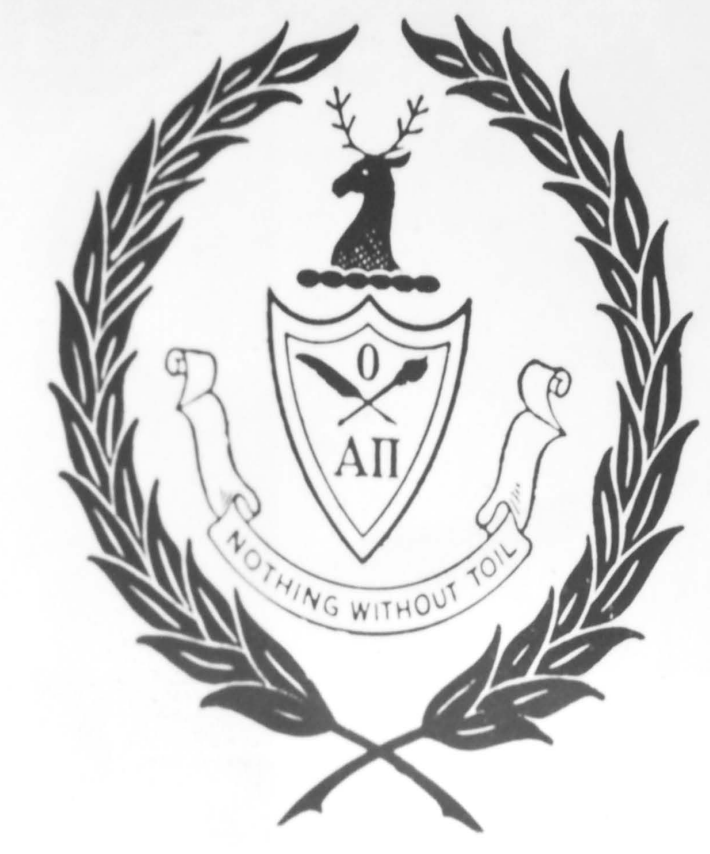

FIGURE 16

Kentucky Home SchoqI Shield 
Since the school color's are black and gold the design is usually enbossed in gold with the background of the shield in black.

Zearbook. The yearbook was also an inspiration of Miss Calhoun. The first volume was published in 1909. The senior class edits the yearbook and since there were seven members of tho senior class of 1909, the yearbook was called The Ploiades. There were the usual photographs of the students, a literature section and resumes of the year's activities. For a first venture, it was a commendable pub20

lication that was sold for ninety-five cents.

\section{Calhoun Club. The Plelades explains the Calhoun}

Club in the following words:

When she opened the school in the fall of 1908 she suggested that the girls should form an organization which should have two main objects: one, to promote the desire for knowledge and the attainment of a highor standard in scholarship; the other, to assist in the education of some worthy Kentucky giri. The pupils accepted the suggestion gladly, and immediately proposed that the organization should be called the Calhoun Club, a name which was unanimously adopted.

When the club was fully organized the members decided to establish a fund for a scholarship and to name it in honor of Miss Belle Peers, the founder of the school. As soon as this was fully decided upon, the club engaged a place at Vassar College for the ensuing year so that a prospective candidate for the scholarship should not be without a room on the empus.

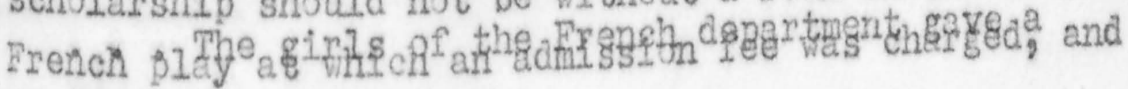

20 Girls, 1915). 
the proceeds vere given to the club for the benefit of the scholarship fund.21

The First Baseball Team. The first baseball team for girls in Louisvillle was organized in 1909 at Kentuciky Home School. "The back yard, though not the regulation diamond size, afforded plenty of space for a three base hit or home $\operatorname{mun}^{10}$

Special clothes for physical education had not come into style yet. Although a few inches had been removed from the length of skirts and they were now ankle length, the girls' game of baseball must have had these limitations besides one's ability to bat the ball or to catsh it . Yost of the girls wore shirtwaists and skirts, the same mode of dress for school as is popular today, but the design is considerabiy different. The shirtwaists had tightly fastened collars and bows or ties were worn with them. They also had long sleeves which were very full at the armole. Many of the younger girls had long hair done in curls or braids, but a.ls of the older girls wore their long hail piled around their heads in pufis not unlike the present day bouffant styles.

21

Ibid.

22

Pandaisia 1915, o․ cit., p. 11. 
Miss Lolia Calhoun. Miss Calhoun contributed to many facets of the fleld of education. She was graduated from the University of Kentucky and attended Columbia University. When she became princlpal of Kentucky Home School she introduced nany new Ideas which have contributed to its being a benefit to the community. Her philosophy of education speaks through these words:

Thoroughness and the development of a capacity for self-culture will be the fundamental principles dominating every department of the school,

Individual attention will be given to each pupil, and her work will be arranged to meet her special needs.

Evory effort will be made to teach the pupil, how to think for herself, and how to give propse expression to her thoughts. 23

The Principal thoroughly believes that the school should be refined, cultured, Christian home, where there are no restrictions that are unnatural and irksome, but where a girl can do her best work, and develop her womanhood along the noblest lines, in an atmosphere of happiness, of sympathy, and of tencer consideration. 24

In later years Miss Calhoun, who was then Mrs. Peter Leidenger, was associated with many endeavors, a.ll related to education. In 1921 she became the first woman member of the Louisville Board of Education. Upon her election to the school board the following comment was made:

No one is more interested in the teaching and train-

23

\section{Ibid. \\ 24 \\ Ibid.}


Ing of children than wozen, and Mrs. Leldenger is a woman who knows the business from $\mathrm{A}$ to $\mathrm{Z}$. She is, moreover, a charming wonan, cultured and refined, w111 do her duty conscientiously and more than justify the wisclom of her selection for the place. $25^{\circ}$

Mrs. Leidenger was elected President of the Louisville Board of Bducation, the first woman to recelve this honor.

During the second year of Miss Calhoun's direction of Kentucky Home School she married Peter Leidenger and at the end of the 1909-1910 school year she sold the school to Viss Annie Stuart Anderson and Miss Annie So Waters. This completed another period in the history of Kentucky Home School. 


\section{CHAPTER V}

KEITTUCKY HONB SCHOOL FROM 1910 TO 1913 


\section{CHAPTER V}

KENTUCKY HONE SCHOOL EROM 1910 TO 1913

Introduction. Chapter V will trace the development of Kentucky Home School from 1910 when Miss Annie. Anderson and Miss Annie Waters became principals until 1913 1ts fiftieth anniversary, emphasizing the intellectual and moral guidance it gave to its students as well as its participation in community living. Many new ideas developed and became part of the school tradition.

Miss Annie Anderson. Miss Anderson was a graduate of Columbla University where she had also recelved a Master's degree. She taught in the Louisville Public Schools and the Hathaway Brown School in Cleveland, Ohio before heading the college preparatory department of Kentucky Home School in 1910. The next year she and Annie Waters purchased the school from Mrs. Leldenger.

Miss Anderson took a great interest in public affalrs and during World War I spoke in behalf of the Federal Food Administration and later for the League of Nations.

In 1919 Miss Anderson assisted in forming the parent-

1

Bess A. Ray (ed.), "A Dictionary of Prominent Women of Louisvilie and Kentucky" (Louisvilie, Kentucky: The Louisville Free Public Librory (mimeographed), 1940), p. 232. 


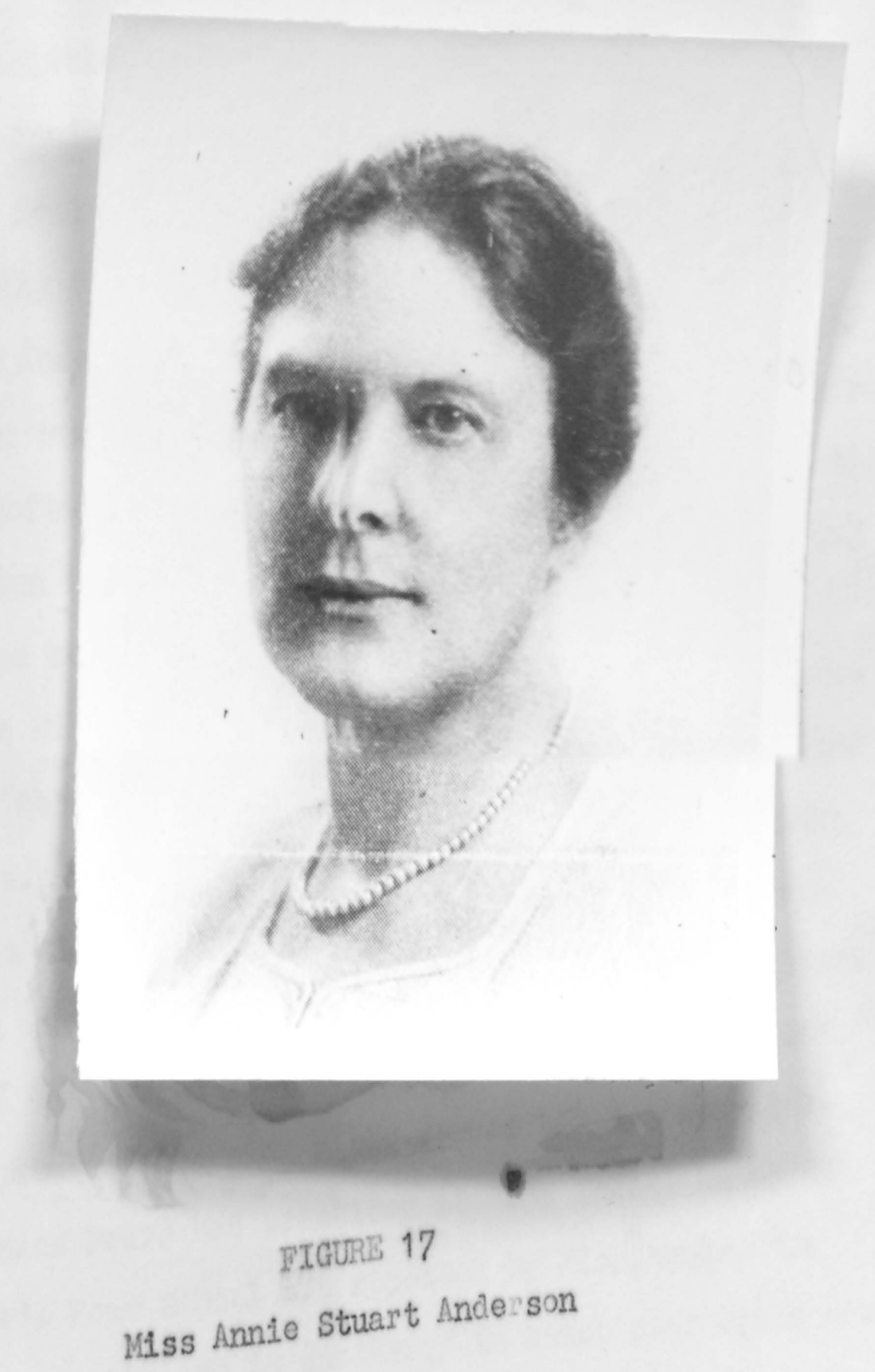


teacher associations throughout the state.

Miss Annie was especially interested in history and d1d a great deal of research principally on early Kentucky history. Many of her articles were published.

Miss Andorson and Miss Waters were both tall, amply proportioned women and usually dressed in black. They were cultured, soft-spoken ladies. One of her students said that Miss Anderson was a bit frightening upon the first meeting but that one soon felt her understanding and sympathy.

Like Miss Peers, Miss Anderson was a devout Episcopalian and there was a dominant Christian influence in the school 1ife. A chapel service was conducted each morning; verses from the Bible which Miss Hattie Audubon had given the sehool were read and hymns appropriate for the varlous seasons of the church year vere sung. Miss Annie revived. the old custom of learning Bible verses but not so rigorously as Miss Peers had practiced it. The School Rules of Miss Belle's Home School oft repeated by Miss Annie, "Be kindly affectioned one to another;/ In honor preferring one another; ${ }^{3}$ characterize the school of this period especially.

\section{2}

\section{Ibid.}

3 1875-1876 (Loulsville, Ky.: John P. Morton and Company, n.d.), p. 3 . 
Miss Annie Vaters. Miss Waters was a native of the Bast. She began her teaching career in Louisvilie in 1900 and was affiliated with Kentucky Home School in 1909 as Head of the Primary and Intermediate Departments. When she became co-principal in 1910 she supervised the Lower School. Girl Scouts was one of Miss Waters special interests. She assisted the Kentucky Home School troop and for twenty years was secretary of the local Girl Scout organization.

1220 Fourth Street. The home of Kentucky Home School was a large brick residence at 1220 Fourth Street from 1904 to 1927 . This was the period of the old-fashioned parlor filled with the family's best and most uncomfortable Victorian furniture and decorated with lace dollies and family pictures. It was used for company only. Kentucky Home School had just such a parlor and the students were never permitted in it except for very, very special occasions. It was reserved for conferences with parents and visiting dignitaries.

The second floor rooms were used for classes and the third floor was taken up with what was called the "ballroom." It was an assembly room which seated about one hundred and had a small stage at one ond. It was used for

4 "Scrapbook," Kentucky Home School for Girls Líbrary. 


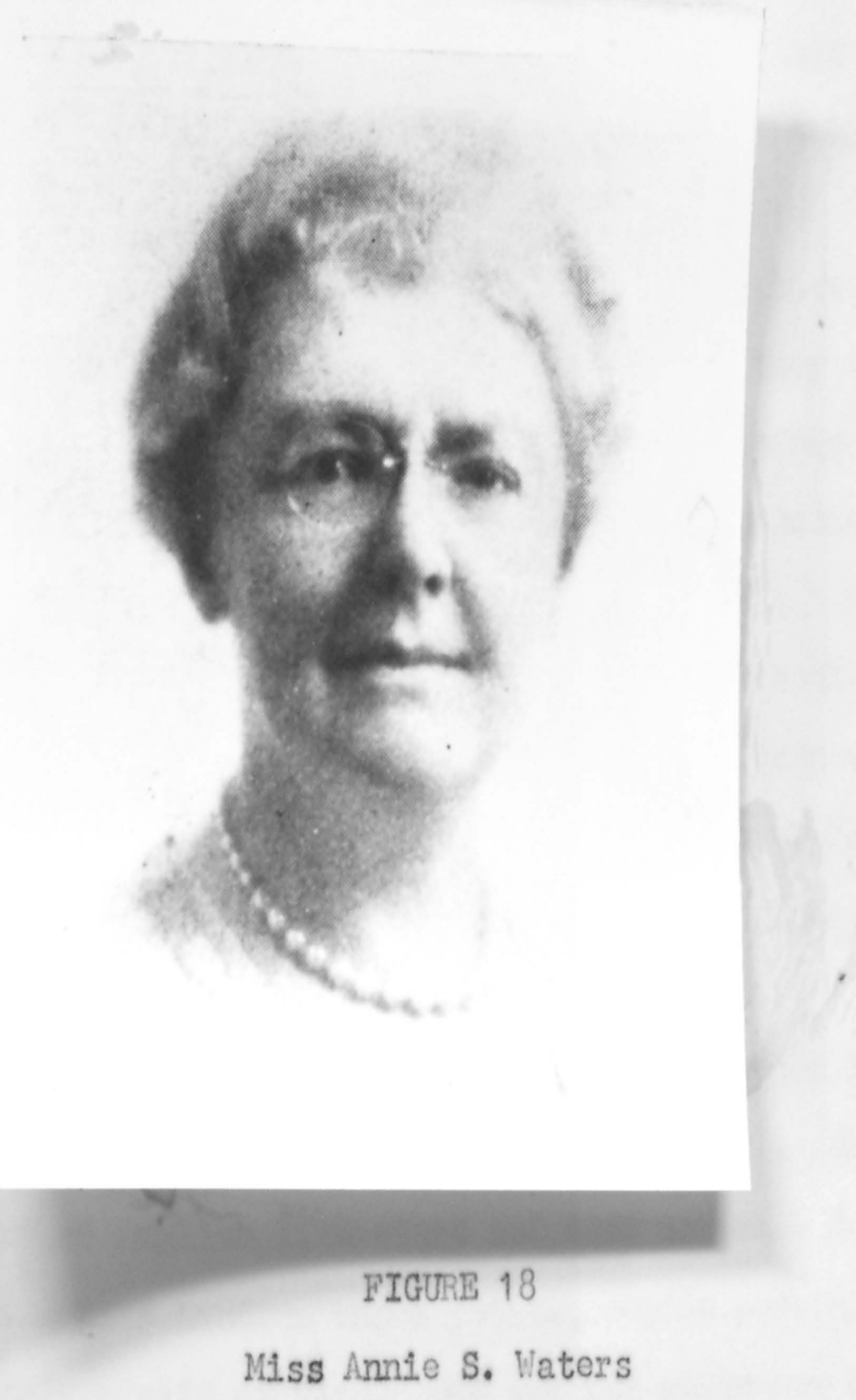


chapel and assembly programs.

Each morning when the gong sounded the girls would march from their second floor classrooms to the third floor ballroom for opening exercises.

One day the menbers of an Upper School class had been punished for some misdeed, unjustifiably they thought, so they painted the steps to the third floor before school the next morning. No one could go to chapel because of the wet paint.

Faculty. The faculty of Kentucky Home School was staffed by experienced teachers, many of them outstanding scholars in their field. Miss Jane Akin, whon we have already mentioned, began the first kindergarten classes in 1910.

Miss Grace Warren Landrum spent part of her long, notable teaching career at Kentucky Home School. She was a student of English 11terature and cane to teach Inglish in 1910. Miss Landrum was a petite, gentle person who was deathly afraid of mice. One day her cless put a mouse In her desk drawer and then asked for something that caused

5 vilie: Kentucky Home School for Girls, $\frac{1910-1911}{\text { School (Louls- }}$ Girls, 6 Ibid. 
her to open the drawer. When she did and saw the mouse she fainted. Immediately Miss Anderson arrj.ved at the scene and frightened the girls, who had monentarily laughed in great amusement, by telling them Miss Lanormum was dead.

In 1916 Miss Landrum left to become professor of

Inglish and head of the department at Tennessee College. It was the writer's privilege to know Dr. Landrum during the nineteen-thirties when she was a professor of English and Dean of Women at the College of William and Mary. What a rare pleasure It was to have tea with the Dean at her colonial cottage and hear her read or recite from some work of Inglish literature,

To study abroad was not as easily accomplished as it is now but some of the faculty did study in Europe. Miss Landrum studied at Oxford University, England. Miss Agatha Bullitt, a graduate of the school, studied in Germany and then returned to teach Germon. Miss Adela. Howard, the plano teacher, was a student of several vell-known German planists. Miss Molly Coyle, who joined the faculty in 1912, later studied in Rowe and then earned her Doctor's degree at St. Louis University.

Miss Ellen Pope Galt, whose art work is vell known In Louisvilie, began teaching art at Kentucky Home School in 1910. She had been a student of Art Institutes in Cincinnati, Chicago, New York, and Montreal. 
Course of Study. The Primary and Intermediate Departments had changed little under the Misses Anderson and Waters. In comparing the content of the courses of study of this period with those of earlier years, there is little difference in the basic skills that vere taught. The great change has been in how they were taught. This change began when studies in child psychology were made.

In the Upper School there was still the choice of the acadernic course for those who would terminate their education; and the college preparatory course. By comparing Figure 14 with Figure 19 and Figure 15 with Figure 20 1ittle difference is found between the courses of 1908 and 1911 although there had been a change of principals. Latin was offered for a half year in the sub-freshman or. elghth grade year. Botany and physlology were shortened to halfyear courses and astronomy and geology were no longer offered

The quality and not quantity of the courses determine the caliber of a school, however, Vassar and Wellesley accepted the girls who had completed satisfactorlily the college preparatory course without further examinations. Kentucky Home School was also accredited by the Southern

\section{7}

Kentucky Home School for Girls, 1910-1211, op. c1t. 
UPPER SCHOOL-OUTLINE OF THE ACADEMIC COURSE

\begin{tabular}{|c|c|c|c|c|}
\hline SUb-Freshiman & Frgshman & SOPHOMORE & JUNIOR & SENIOR \\
\hline $\begin{array}{c}\text { English } \\
\text { (one-half year) } \\
\text { Latin } \\
\text { (one-balf year) }\end{array}$ & English I & English II & English III & English IV \\
\hline $\begin{array}{l}\text { Arithmetic } \\
\text { and } \\
\text { Algebra }\end{array}$ & Algebra II & Geometry & Chemistry & $\begin{array}{l}\text { Economics and } \\
\text { Civies }\end{array}$ \\
\hline French or German & $\begin{array}{c}\text { French I } \\
\text { or German I }\end{array}$ & $\begin{array}{l}\text { French II } \\
\text { or German II }\end{array}$ & $\begin{array}{l}\text { French III } \\
\text { or German III }\end{array}$ & History of Art \\
\hline $\begin{array}{c}\text { Physiology } \\
\text { (one-half year) } \\
\text { Botany } \\
\text { (one-balf year) }\end{array}$ & Latin I & Latin II & $\begin{array}{c}\text { Latin III } \\
\text { (without Prose } \\
\text { Composition) }\end{array}$ & $\begin{array}{l}\text { Latin IV } \\
\text { elective) }\end{array}$ \\
\hline \multirow[t]{2}{*}{$\begin{array}{c}\text { United States } \\
\text { History } \\
\text { (Completed) }\end{array}$} & English History & $\begin{array}{c}\text { Greek or Roman } \\
\text { History }\end{array}$ & $\begin{array}{l}\text { Medixval and } \\
\text { Modern History }\end{array}$ & American History \\
\hline & & & $\begin{array}{l}\text { Solid Geometry } \\
\text { (elective) }\end{array}$ & $\begin{array}{c}\text { French or German } \\
\text { (elective) }\end{array}$ \\
\hline \multirow[t]{2}{*}{$\begin{array}{c}\text { Art } \\
\text { (elective) }\end{array}$} & $\begin{array}{c}\text { Art } \\
\text { (elective) }\end{array}$ & $\begin{array}{c}\text { Art } \\
\text { (elective) }\end{array}$ & $\begin{array}{c}\text { Art } \\
\text { (elective) }\end{array}$ & $\begin{array}{c}\text { Art } \\
\text { (elective) }\end{array}$ \\
\hline & & & & $\begin{array}{l}\text { Psychology } \\
\text { (elective) }\end{array}$ \\
\hline
\end{tabular}

\section{PIGURB $19^{*}$}

IPIER SCHOOL-OITLINE OF THE COLL.EGE PREPARATORY COURSE

\begin{tabular}{|c|c|c|c|c|}
\hline Sta-Fxrumsax & Fersumax & SOPHOMORE & JUNIOR & Senior \\
\hline $\begin{array}{c}\text { Eaglish } \\
\text { (one-half year) } \\
\text { Latin } \\
\text { (oac-hali year) }\end{array}$ & English I & English II & English III & Review of English \\
\hline $\begin{array}{l}\text { Arithmetic } \\
\text { and } \\
\text { Algebra }\end{array}$ & Algebra II & Geometry & $\begin{array}{l}\text { Chemistry } \\
\text { (elective) }\end{array}$ & $\begin{array}{l}\text { Review of } \\
\text { Mathematics }\end{array}$ \\
\hline French of German & $\begin{array}{c}\text { French I } \\
\text { or German I }\end{array}$ & $\begin{array}{l}\text { French II } \\
\text { or German II }\end{array}$ & $\begin{array}{l}\text { French III } \\
\text { or German III }\end{array}$ & $\begin{array}{l}\text { Review of French } \\
\text { or Review of German }\end{array}$ \\
\hline $\begin{array}{c}\text { Physiology } \\
\text { (one-half year) } \\
\text { Botany } \\
\text { (one-halif year) }\end{array}$ & Latin I & Latin II & $\begin{array}{c}\text { Latin III } \\
\text { (with Latin Prose } \\
\text { Composition) }\end{array}$ & $\begin{array}{c}\text { Latin IV } \\
\text { (with Latin Prose } \\
\text { Composition) }\end{array}$ \\
\hline \multirow[t]{2}{*}{$\begin{array}{l}\text { Caited States } \\
\text { History } \\
\text { (Completed) }\end{array}$} & English History & $\begin{array}{c}\text { Greek and Roman } \\
\text { History }\end{array}$ & & $\begin{array}{c}\text { American History } \\
\text { (elective) }\end{array}$ \\
\hline & & $\begin{array}{c}\text { Greek } \\
\text { (elective) }\end{array}$ & $\begin{array}{c}\text { Greek } \\
\text { (elective) }\end{array}$ & $\begin{array}{c}\text { Greek } \\
\text { (elective) }\end{array}$ \\
\hline
\end{tabular}

Changed according to requirements of the College to be entered. 
Assoclation of Colleges and Secondary Schools.

Beginning with the school Bulletin for 1910-1911

there is a complete 11st of the texts and their authors for the Upper School classes. This was a customary prace. tice of this ora.

Muition. Boarding students were st111 accepted and a Miss Florence Falrfax Stone supervised the hone life of these girls so 1 was called the Home Department. $A \$ 500.00$ fee was charged for room, board, and tuftion in all the regular branches.

The 1910 tuition for kindergarten was $\$ 50.00$; the Prinary Department, $\$ 100.00$; the Intermediate, $\$ 135.00$; subfreshman, $\$ 150.00$; freshman, sophomore, junior, and senior academic years, $\$ 175.00$; the junior and sentor preparatory years, $\$ 200.00$. The tuition for the Intermediate Department hac Increased $\$ 10.00$ and In the Upper School $\$ 25.00$ to $\$ 50.00$ had been added to the tuition of all the classes except the sub-freshman. 10

Special rates were made for the daughters of clergymen.

8

IbId.

9

Ibic.

10

Ibig. 
Aims. The aim of Miss Anderson and Miss Waters was "to give the best intellectual training, and to develop a self-reliant, Christian womanhood." This suggests that the school was still concerned only with the intellectual. and moral development of the student. The emotional, and physlcal well-being of a child were not generally thought to be important factors in the learning process in the early part of the nineteenth century. The principals recognized. the close association of the home and school, because they suggest that parents confer frequently with them concerning the children's work. "It 1s only by the earnest cooperation of parents and teachers that the best results be ob12

tained." Parents vere urged to cooperate with the school in maintaining punctuality, regularity in attendance, and study hours.

Regulations. There were a number of rules printed in the Bulletin which left no doubt in the pupil's mind about what vas expected of her. Pup1ls were required to make up all work lost by absence or lack of preparation.

11

IbId.

12 Ibอำ. 
The daily session was from $8: 45$ to $1: 30$ but one and a half to two hours home study was suggested for Lower School students. At least two hours and a half study at home was thought to be necessary for each girl of the Upper School. Nore time than this might be necessary in the last years of college preparatory work.

Reports were given quarterly and examinations hold half-yearly, at the end of January and June. 15

The aforementioned regulations were written but there were also sone unwritten laws. Silk stockings were the latest in fashion but Miss Anderson would never permit any of the girls to wear them to school. There was also a new soft drink called Coca-Cola that had a very pleasing taste. Miss Annie thought it contained a stimulant that was harmful to the girls, so 1t was never allowed to be served at school parties. In the eirst yoars of its popularity jazz was also forbidden at the school. It had become stylish to wear vanity cases on a chain around the wrist. Miss Annie frowned upon this and when the girls would open them to powder their noses, she would say, "INot in my presence." Belle Peers Scholarship Eund. When Miss Calhoun

14

IbId.

15

Ibic. 
gave up the school the Calhoun Club also ceased to exist. Its project, the Belle Peers Scholarship Fund, was adopted. by the Alurnae Assoclation. The Alumnae Association had formally disbanded in 1906 but was reorganized In 1911. Through the years it sponsorod many fund-raising projects. It gave a number of plays that wore very successful artistically and financially. Arong them were Siz Anthony in 1913, Her Husband's Hife in 1915, and Creen Stockings in 1916. Mr. Boyd Martin, Louisvilie's drame critic, directed the plays and young men of the city assisted with the 16

masculine roles. Bridge parties, luncheons, teas, and. garden parties have also been held for the beneflt of the Belle Peers Scholarsh1p Fund.

The Belle Peers Scholarship of $\$ 200$ was awarded each year to the senior vith the highest scholastic average who was entering college.

Kountain Fund. Often there were guest speakers who talked to the girls in chapel. In 1912 Miss Linda Neville, secretary for the Kentucky Society for the Prevention of Blindness, spoke to the elrls about her work anong the children of the mountains of Kentucky. The girls were most symathetic and several determined to earn money to give to 
the blind children. "One dear little girl darned the family stockings at a peniny each and the next september poured out her hoard of pennies and nickels . ..." In June of 1913, a fete was held on the lawn of the home of one of the children and resulted in the nucleus of the Mountain Fund. The following year a bazar was held in the chapel and so the Annual Mountain Fund Bazaars began. The girls planned and managed the bazaars. It was quite an honor to be elected chairman.

Kentucky Home School made possible an expedition of a doctor and nurses into Oneida, Kentucky in 1914. This was a remote mountain community and Miss Nevilie and her party had to travel in two wagons and on three saddle horses.

Although Miss Anderson and Miss Waters felt that the spirit of consideration for others was an important principle, nothing must interiere vith the school work and the girls were never excused from classes to make preparations for the bazaar nor was there any respite from homework. The girls worked diligently to assemble articles for the sale, prevaliling upon their families and friends to con-

17 17
for Gir Is (Louisvical
Girls, 1932 , D. 15. 
tribute hand-made articles and home-baked goodies.

The bazaar was held oach year until 1942. At least several hundred dollars was raised annually from 1913 to 1942 except when there was economic prosperity throughout the United States from 1920 to 1929 when as much as eight hundred dollars a year vas raised.

This telegram sent to the girls in 1922 by Miss Heville explains the work.

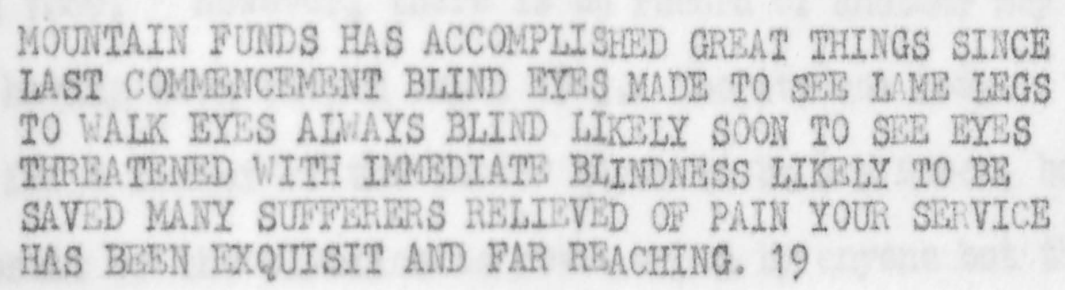

In 1942 the state appropriated funds to do the work the Mountain Fund had been supporting so the annual bazaars were no longer held.

Pandaisia. The Class of 1909 edited the first Kentucky Home School yearbood which was called Plelades. The followIng year it was expedient that the name be changed since there were only five members of the senior class. They chose the name Pandalsia-ma feast in which all may partake-"hoping thus to indicate the spirit of good-fellowship and

18

Annie Anderson, "Iotes."

19

"Scrapbookg" Kentucky Home School for Girls Library. 
co-operation which we hold as the ideal of our comon life 20

beneath the school roof." Each succeeding year the annual has been published by the seniors. It is a record of the year's activities including pictures but its outstanding feature is the literary work. Both poetry and prose contributions are made by talented members of a.11 classes.

May Queen. In the notes of Miss Annie Anderson there is mention of Lena Bartlett having been the first Queen of 21

Nay in 1869. However, there is no record of another May Queen having been chosen unt11 1913. The student body votes for a member of the senfor class to be May queen, but the result of the election is never known by anyone but the Principal until the day of the fostivities when the chosen Queen is escorted to her throne by a herald. The first May Day Festivals were held in the schoolyard and the Queen walkod under a leafy canopy uphold by four sub-freshmen. After the Queen read her poetic proclamation, the Lower School Departmonts danced an intricate May Pole Dance.

20 Home School for Giris, 1910).

"Lditorial," Pandaisia (Louisville, Ky.: Kentucky

21 Annie Anderson, "Notes."

22 for Girls, 1914), p. 39 . 
Since 1913 there has been a May Day program each year on the first of May unless the weather forces it to be postponed unt1l the next clear day.

Commencement. Since the first class was graduated in 1876 there has beon 11 ttle change in the commencement program. The graduates have always worn white dresses and carried arm bouquets of flowers. The programs are essentially the same, although the Salutatory and Valedectory addresses were discontinued in 1885. Musical numbers played by talented students are st111 a part of the program. In the early part of the nineteenth century the speakers were local clergymen. Part of the comencenent tradition is that it is held at the Woman's Club. This began in 1911 but was interrupted from 1918 to 1924. The original Woman's Club building was destroyed by fire and a new club building was not built until $1924 .{ }^{23}$

The number of graduates has varied each year from two to fourteen. However, no one received a diploma in 1904 and 1905.

Kontucky Home School Continues. After eifty years of guiding girls through their years of learning, the Kentucky Home School for Girls had earned a creditable reputation.

23 "Scrapbook," Kentucky Home School Library" 
It had altered its program to meet the needs of young women whose place in society was rapidly changing but at the same time kept the vorthwhile traditions. Thus the foundations for the continuance of the school had been firmly established, 
CHAPTER VI

SUMUAYY AND CONCLUSIONS

I 
Sumpary. Miss Belle Peers conducted prinary classes in a room over the vestry of Christ Church in 1863. This was the beginning of Kentucky Home School. She taught her classes in Mrs. Field's school building in 186\%. In 1868 Miss Peers jolned with the Misses Henrietta and Loulse Barbaroux. The combined schools were located at 12 East Chestmut Street for three years. In 1871 Miss Belle opened her own school again at 209 second street. She moved to a large house on Third street in 1880 in order that she might accomodate boarding students. The tuition for the Primary and Junior Classes was $\$ 60.00$ and for the Middle and Senior Classes $\$ 80.00$. French, German, and Latin were extra and the boarding fee was $\$ 340.00$. in 1879 the classes were reorganized and the number of years work increased from elght to ten. The Kentucky State Legislature granted the school a charter and authorized the creation of a Board of Directors. There were eight prominent Loulsville businessmen who served on the board. Toward the end of the nineteenth century changes were made in the course of study to meet the needs of young girls who were to continue thets education. In 1902 Miss peers moved the school to a house opposite Central Park and in 1904 sold it to Miss Davison 
and Miss Dodge. Many able and prominent teachers were members of Miss Belle Peers' staff. They included Noble Butler, Harriet Audubon, Bllen Whittier, and Fannie Anderson. A number of the students have contributed to Loulsville's culture and to the welfare of others.

Miss Ellen Davison and Miss Louise Dodge bought the school in 1904 and held classes in a house at 1220 Fourth Street. By this time the tultion rates had doubled. BoardIng stucients were still accepted, The course of study was designed primarily for girls who would terminate their education upon graduation but those who wished to attend college were given the necessary preparation. For the first time students were given some choice in the subjects they would study for there were prescribed courses and then a group from which one might make a choice.

Miss Lella Calhoun purchased the school in 1903. It was st111 located at 1220 Fourth Street but Miss Calhoun again called It Kentucky Home School for GIrls, MIss Calhoun made some innovations in the course of study. The Upper School was divided Into two different departments; the academic, a five year course with diploma, and the college preparatory, four years with cert1ficate. Miss Calhoun inspired many new projects, such as the Calhoun Club, the first baseball and basketball teams, the first yearbook, and the adoption of a school shield and motto. 
In $1910 \mathrm{Mrs}$. LeIdenger (Miss Calhoun) sold the school to Miss Annie Waters and Miss Annie Anderson. More emphasis was placed on preparing the students to attend college, for about seventy-five percent of the graduates were continuing their education. Many capable teachers were added to the staff. A Mountain Fund was created to help less fortunate people in the Kentucky mountains. May Festivals for which a May Queen was chosen were started.

Many changes had taken place in Kentucky Home School from 1863 to $1913 \mathrm{in} \mathrm{keeping} \mathrm{abreast} \mathrm{of} \mathrm{the} \mathrm{changing} \mathrm{times,}$ customs, and intellectual advancement.

Conclustons. From the beginning of the school its ain was to develop a desire and a capacity for self culture. This was accomplished not only through a program of studies designed to exercise mental discipline and to give insight Into many varied fields but also by the examples set by the faculty, intelligent, refined educators who had attained this goal. As women were permitted the same educational opportunities as men the students were being prepared to take advantage of this.

The moral character of the students was fostered through Bible study and a close relationship with Bishop Dudley and the cultivation of honesty, dependablilty, unseleishness, a spirit of service and consciousness of community and world need. 
Developing emotional maturity is of more recent concern than this study covers but the iast fow years included in this survey show the beginning of this trend. The coopm eration of the students in accomplishing group projects promoted satisfactory relationship with others.

The physical health of the children has been always considered an essential part of their education. The type of activity changed from the delicate motions of calisthenLes to the more rigorous team sports.

After having compiled this history it is the opinion of the writer that the following conclusions are justified:

1. The philosophy and aims of the school are in agreenent with the general concepts of education of the period.

2. The curriculum of Kentucky Home School reflects the change of woman's place in society.

3. The history of the school reflects the economic, social, and financial changes of the times.

4. Kentucky Home School has been a private enterprise, and the principals and faculty have been Irportant factors in determining its success.

5. This thesis may become a means of renewing memories for those who have been a part of the school. 6. This thesis w111 be a valuable reference source to the administration of the Kentucky Home School. 
because it is the only one of its kind in existence. 7. The study of a second language (French or German) in the elementary grades has been a part of the course of study since 1895. 


\section{BIBLIOGRAPHY}

\section{BOOKS}

Acts of the General Assembly of the Commonwealth of Kentucky at the Regular Session of the General Assembly Which was begun and held in the city of Erankfort on Mond y, the twenty-oighth day of November, Lighteen hundred and elghty-one. Frankfort, Kentucky: Kentucky Zeomen fice, 1882.

Briney, Melville. Fond Recollections. Loulsville, Kentucky: The Loulisvi11e Times. 1955.

Cubberley, Ellwood P. Educetion in the United States. New York: Houghton Mifflin Company, 1919.

Dabney, Charles William. Universal Education in the South. 2 vols. Chapel Hill: The University of North Carolina Press, 1936.

Dexter, Edwin Grant. A History of Education In the United States. New York: The Kacmilian Company, 1916.

Johnston, J. Stoddard (ed.). Memorial, History of Louisvi11e. Chi ago: American Blographical Publishing Company, 1896.

Knight, Edgar W. (ed.). A Documentary History of Education in the South Before 160.4 vols. Chape1 Hi11: University of North Carolina Press, 1953.

Mcheekin, Isabel HeLennan. Louisville, The Gateway City. liew York: Jultan Messner, Inc., 1946.

MoVey, Frank Lo The Gates Open Slowly Lexington: University of Kentucky Press, 1949.

Monroe, Paul (ed.). A Cyclopedia of Education. 5 vols. New York: The Kacmilian Company, 1926.

Panda1sia. Louisvi11e: Kentucky Home Sch ol for Girls, 1910. Pandaisla. Luuisville: Kentucky Home School for Girls, 1915. The Pleiades. Louf sville: Kentucky Home School for Girls, 1909. 
Reibel,R.C.(ed.). Louisville Panorama. Louisvilie, Kentucky: Liberty Iational Bank and Trust Company, 1954.

Seybolt, Robert Francis. The Private Schools of Colonial Boston. Cambridge: Harvard University Press, 1935.

Thompson, Eleanor Wolf. Educetion Lor Ladies, 1830-1860. Morningside Heights, New Yor'k: KIng's Crown Press, 1947.

Woody, Thomas. A History of Womon's Bdu ation in the United States. 2 vols. New York: The Science Press, 1929.

\section{BULLETINS}

Davison-Dodge School for Girls. Lovisvilie: n.n., 1906.

Bulietins of The Kentucky Hone School for Girls.

An annual bulletin has been printed since 1874. The issues found and used in this thesis are for the years $1874-1875,1875-1876,1879-1880,160-1881,1812-1883$, $1884-1885,1886-1887,1888-1889,1839-1890,1890-1891$, $1892-1893,1893-1894,1895-1896,1896-1897,1897-1893$, $1898-1899,1899-1900,1900-1901,1908-1909,1909-1910$, $1910-1911,1911-1912,1912-1913,1913-1914,1914-1915$.

Ligon, Moses Edward. A History of Public Edu:ation in Kentucky. Bulletin of the Bureau of School Services, College of Bducation of the University of Kentucky, Vol XIV. Lexington: University of Kentueky Press, June, 1942.

\section{PAMPILITS}

An $\frac{\text { Historical }}{\text { Sousivilietch of }}$ : Kentucky Hentucky $\frac{\text { Hone Sohool }}{\text { Home School for Girls, }} \frac{\text { Girls, }}{932 .}$

Knight, Edgar W. The Acadeny Movement in the South.n.p.: University of North Carolina, n.d.

Louisville Female Seminary, 39th Annual Prospe tus.

01d Louisvil1e. Louisville, Kentucky: University of Louisvilie, 1961. 


\section{NEWSPAPERS}

Courier Journal, January 30, 1916.

Herald Bost, September 19, 1921.

The Louisvilie Daily Focus $\frac{\text { For }}{10,11}$, and 29, 1831.

Louisville Daily Gazette

Issues of Apri1 6 and October 6, 1841

Louisville Daily Journal, August 18, 1863

The School-Be11, June 1877. (Kentucky Home School P1les)

\section{UNPUBLISHED MATERTALS}

Anderson, Annie Stuart. "Notes." Kentucky Home School files. Humel, Elizabeth. "Noble Butler: Louisvilie Bducetor and Author." Unpublished Master's thes1s, University of Louisvil1e, 1962.

Kendrick, W11liam Carnes. "Old Reminiscences of Loulsville." Loulsvilie: n.d. (mimeographed)

Ray, Bess A. (ed.). "A Dictionary of Prominent Women in Louisvilie and Kentucky." Iouisvilie, Kentucky: The Louisvilie Free Public Library, 1940. (mimeographed)

Wolff, Florence K. "The Study of Girls Schools in Louisville Prior to 1900." Unpublished professional paper, University of Louisville, 1951. 